\title{
PODVRŠJE - GLAVČINE: RESULTS OF THE MOST RECENT ARCHAEOLOGICAL RESEARCH
}

\section{ANTE UGLEŠIĆ}

UDC: 726.54(497.581.1)"04/o5" 902.2

Review

Manuscript received: 16. 02. 2017.

Revised manuscript accepted: 27. 03. 2017.

DOI: 10.1484/J.HAM.5.113753
A. Uglešić

Sveučilište u Zadru Odjel za arheologiju

Obala kralja P. Krešimira IV., 2 23000 Zadar, Croatia auglesic@unizd.hr

The paper offers an overview of the systematic archaeological research of the early Christian complex Glavcine in the village of Podvršje, situated about $18 \mathrm{~km}$ north-east of Zadar (Ražanac municipality). In eight archaeological campaigns, in the period from 2002 to 2015 a complex of double churches (geminae) with auxiliary rooms was excavated, made in two building phases in the 5th and 6th century. Early Christian complex was built at the position of an earlier round structure which is assumed to might have been a Roman temple dedicated to Syrian gods (tholos?). A smaller room with an apse also predates the building of the churches. It was built within the ruins of the round structure, and it is believed to have been an Early Christian oratory.

Keywords: double churches, geminae, Ljubač, Podvršje, Early Christian architecture

\section{INTRODUCTION}

The site of Glavčine is located south-west of the village of Podvršje, about 300 m east of the road leading to Ražanac and Pag (fig. 1). This position belongs to the wider area of the present-day village of Ljubač, as one of the richest regions in archaeological sites in Croatia. Settling of this area started from the Middle Palaeolithic period. Multitude of flint fragments, flakes and partially worked artifacts dating from the Middle Palaeolithic to the Early Bronze Age can be found on the natural ridge (slope) north of the settlement spreading almost $15 \mathrm{~km}$ in length, all the way to the village of Posedarje. Archaeological remains are particularly abundant on the north-western side of the slope, above Ljubač, on the position Kosa (Ljubačka kosa) and above the village of Podvršje, on the position Matakov brig. Large Liburnian cemetery with over a hundred burial mounds, and as much as seven hillfort settlements are located in the area from Ljubljana cape (or a strait separating mainland from the island of Pag) to Podvršje, measuring four to five kilometers in length. ${ }^{.}$Hillfort Ljubljana on the end of the Kosa cape is of particular importance. It has been inhabited from the Iron Age to the Ottoman raids. A strong fort was built on this position as early as the Justinian's era (the first half of the 6th century). Presence of a very important medieval fort Castrum Liube was mentioned in the 13 th century. ${ }^{2}$ This fort was the center of the Ljubač district until the Ottoman raids. Archaeological sites from prehistoric, Roman and medieval period were found in the areas of the Plemići and Ljubačka vala bays, as well as in the surroundings of the villages of Ljubač, Ljubački Stanovi and Podvršje and in their fields. ${ }^{3}$

\section{OVERVIEW OF PREVIOUS RESEARCH}

The position of Glavčine is located on the plot no. 52/64 of the cadastral community Radovin, in possession of several families with surname Matak so it is also known as Matakove njive. An inconscpicuous mound less than $1 \mathrm{~m}$ high was also located in this area. In 1997 one of the owners wanted to level the terrain and tear down the mound to enable tillage. The first dig of the backhoe caught a piece of the wall, and stone fragments appeared in the trench: two colonnettes with capitals, several pilaster fragments, marble column fragments, and several slab fragments. The landowner stopped digging immediately, and reported the find to the custodian of the Archaeological Museum in Zadar at the time, dr. sc. Zdenko Brusić who came to the site and collected the finds together with the owner.

According to the landowner, back in 1939 the works were undertaken at the site of Glavčine with the aim of levelling the mound unearthing thereby an early Christian sarcophagus with a lid. In the same year a grave made of worked stone slabs was found as well as another "slab" with an inscription, several threshold fragments, and several fragments of architectural stone elements. Walls were also uncovered but stones were taken off them. The works were terminated due to emergence of multitude of walls. Sarcophagus was left at the site, but a bomb was thrown into it in the Second World

\footnotetext{
${ }^{1}$ A. UGLEŠIĆ, Ljubač, in: Stotinu hrvatskih arheoloških nalazišta (One Hundred Croatian Archaelogical Sites), ed. by A. Durman, Leksikografski zavod Miroslav Krleža, Zagreb 2006, pp. 158-159.

${ }^{2}$ I. PETRICIOLI, Castrum Liube (Neistraženi arheološki lokalitet), Starohrvatska prosvjeta, III. s., 13, pp. 117-122.

${ }^{3}$ A. UGLEŠIĆ, Neobjavljeni nalazi preromaničke kamene plastike s područja sjeverne Dalmacije, Radovi Filozofskog fakulteta u Zadru, Razdio povijesnih znanosti, 31(18), Zadar 1993, pp. 143-154; B. MARIJANOVIĆ, Jokina glavica - prapovijesni grobovi, in: Tumuli iz Krneze i Podvršja (Tumuli from Krneza and Podvršje near Zadar), ed. by B. Marijanović, Sveučilište u Zadru, Zadar 2012, pp. 15-47; K. GUSAR, Jokina Glavica - ranosrednjovjekovni grobovi, in: Tumuli iz Krneze i Podvršja, pp. 49-83; K. GUSAR, D. VUJEVIĆ, Duševića glavica, in: Tumuli iz Krneze i Podvršja, pp. 103-135; K. GUSAR, D. VUJEVIĆ, Matakova glavica, in: Tumuli iz Krneze i Podvršja, pp. 151-173.
} 


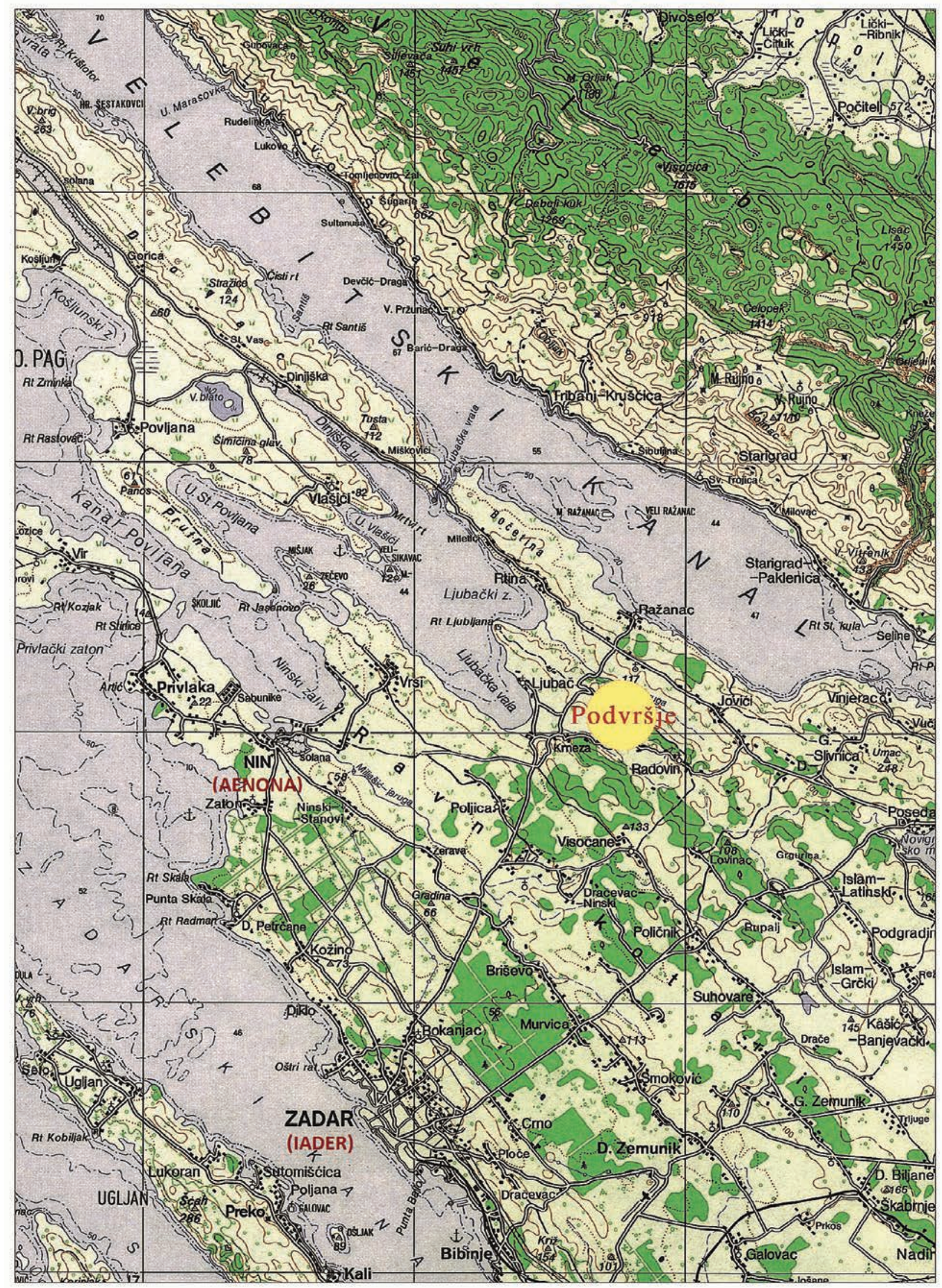

Fig. 1. Village of Podvršje as indicated on the map

War so that it was destroyed and some of its fragments were built in the drystone wall enclosure. ${ }^{4}$ Recovered thresholds were incorporated in the family house of the landowner, and fragment of the large slab from the grave is still used to press dry-cured ham. What happened to the rest of the stone fragments remains a mystery, but according to the landowner some of them were taken to Nin in a cart. This is confirmed by two fragments of stella deposited in the

${ }_{4}^{4}$ During the archaeological excavations we dismantled the drystone wall and found six fragments of sarcophagus and concluded that it was a big late antique sarcophagus. 


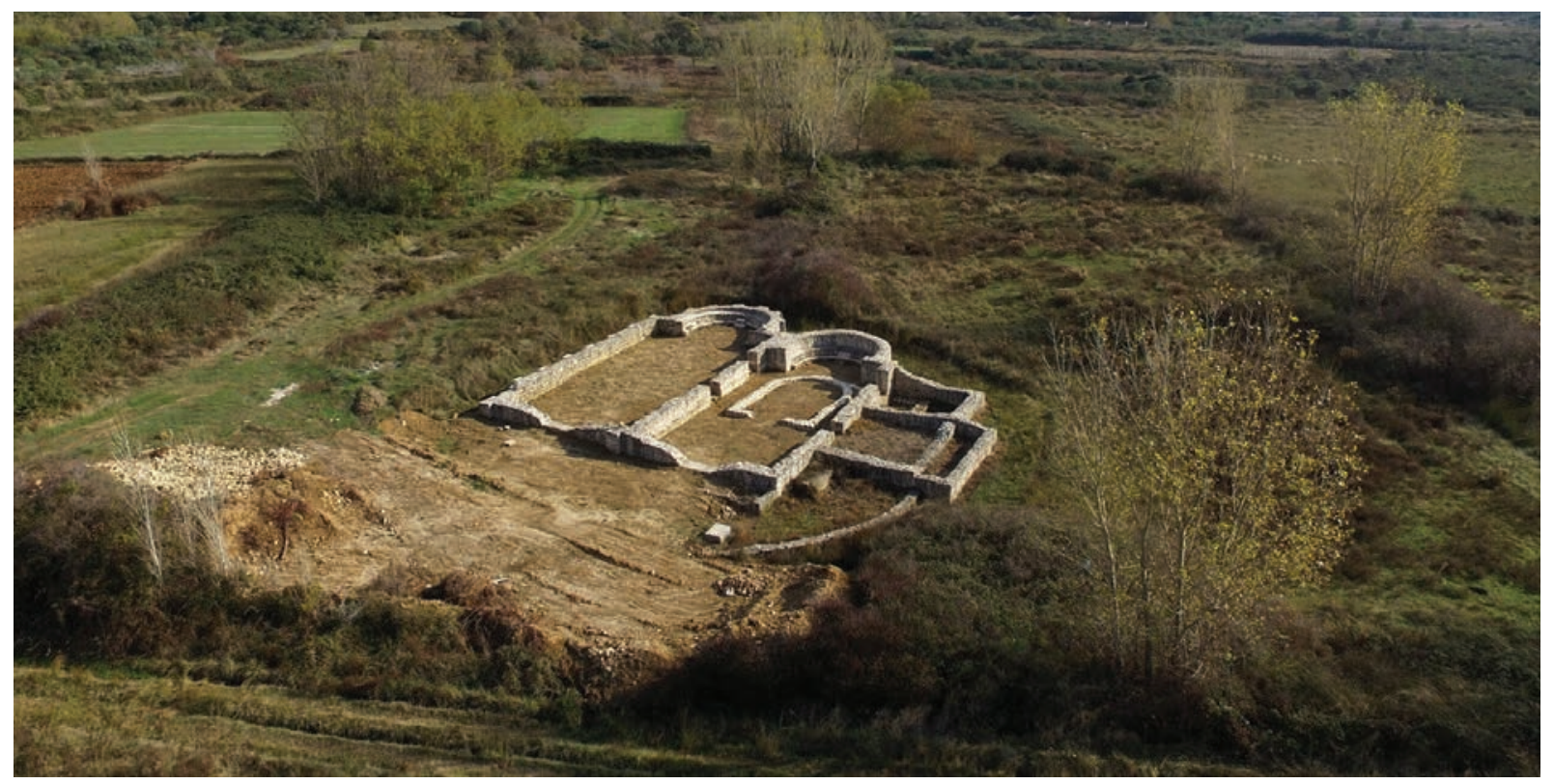

Fig. 2. Aerial view of the site of Glavčine in Podvršje (photo: P. Iglić)

Museum of Nin Antiquities which were conjoined with the upper part of the stella found in the excavations of grave 1 (fig. 27-28). Stella fragments from Nin are probably „slab with an inscription" mentioned by the landowners, found in the attempt of levelling the terrain in 1939.

Mentioned finds were suggestive enough to indicate that this was an important site worthy of archaeological research. Systematic archaeological research commenced in 2002 under the auspices of the Department of Archaeology of the University of Zadar, within the project Archaeology of the Migration Period on the eastern Adriatic led by prof. dr. sc. Ante Uglešić and within the field practice of the 3 rd and 4th year students of archaeology in cooperation with the Archaeological Museum in Zadar. ${ }^{5}$ Surface of about $900 \mathrm{~m}^{2}$ was excavated in the total of six archaeological campaigns - the first during February and March of 2002, the second in May and June of 2002, the third from May to July of 2003, the fourth from May to July of 2004, the fifth in September 2004 and the sixth from May to July 2005. ${ }^{6}$ The research was interrupted until 2012 when the seventh campaign started. The eighth research campaign was carried out from June to September 2015. ${ }^{7}$ Problems during the excavations arose owing to abundance of underground waters related to natural and geographic characteristics of the position of Glavčine located on the lower parts of one of valleys (synclines) of Ravni kotari. ${ }^{8}$

\section{RESEARCH RESULTS}

In the systematic archaeological excavations of the site of Glavčine in Podvršje, an early Christian complex was found consisting of double churches (geminae) with auxiliary rooms, chapel and cemetery (fig. 2-3). This complex was formed at the place of an earlier structure with circular layout and diameter of about 18,5 $\mathrm{m}$ whose foundations are only partially preserved (fig. 3). It is difficult to make any conclusions about the function of this edifice. One of the assumptions is that it might have been a Roman temple, circular in shape (tholos) whose presence is suggested by an inscription used as lining of a monumental tomb and mentioning renovation of the temple dedicated to the Syrian gods (fig. 5). The inscription reads:

C(aius) Albucius l(ibertus) Restitutus/IIIIII vir et flavialis/ Dis Syris templum ampliavit/a solo sua inpensa fecit.

Finds of two earlier floors beneath the original floors of both churches are also interpreted as indications that a temple was located under the complex of double churches. Since renovation of the temple is mentioned on the recovered inscription, it is logical to assume that the lowest floor which is about $30 \mathrm{~cm}$ lower than the church floor might belong to its first phase. Thick layers of soot were found

${ }_{5}$ Owners of the estate allowed us benevolently to conduct archaeological excavations on their land. One of the most important early Christian sites in the wider Zadar region was explored and partially presented owing to their benevolence, help and consciousness of cultural heritage importance.

${ }^{6}$ Professional archaeological team consisted of the research leader prof. dr. sc. Ante Uglešić, prof. dr. sc. Zdenko Brusić, and junior researchers at the time mr. sc. Tomislav Fabijanić and mr. sc. Karla Gusar. Student field practice was managed by prof. dr. sc. Brunislav Marijanović. Custodian of the medieval collecton at the time prof. Radomir Jurić participated in the excavations on behalf of the Archaeological Museum. Cf. A. UGLEŠIĆ, Ranokršćanska arhitektura na području današnje Zadarske nadbiskupije, Filozofski fakultet u Zadru, Odsjek za arheologiju - Zadarska nadbiskupija, Zadar 2002, pp. 45-50; A. UGLEŠIĆ, Dvojne ranokršćanske crkve u Podvršju, Sveučilište u Zadru, Odjel za arheologiju - Arheološki muzej u Zadru, Zadar 2004; A. Uglešić, Dvojne ranokršćanske crkve u Podvršju, Muzej grada Šibenika - Sveučilište u Zadru, Odjel za arheologiju - Arheološki muzej u Zadru, Šibenik 2004; A. UGLEŠIĆ, Ljubač, in: Stotinu hrvatskih arheoloških nalazišta, pp. 158-159; A. UGLEŠSĆ, Glavčine, Podvršje, Hrvatski arheološki godišnjak, 2/2005, Zagreb 2006, pp. 301-304; A. UGLEŠIĆ, J. BARAKA, Podvršje - Glavčine, un novo caso di chiese doppie in Dalmatia, in: Acta XV Congressus internationalis archaeologiae Christianae, Episcopus, civitas, territorium, Toleti (8-12. 9. 2008), II, Città del Vaticano 2013, pp. 1207-1215.

7 The excavations of these two campaigns were financed by the Department of Archaeology. Professional team consisted of research leader prof. dr. sc. Ante Uglešić, doc. dr. sc. Karla Gusar and dr. sc. Jure Šućur.

${ }^{8}$ All campaigns were accompanied by conservation and restoration works whereby all architectural remains at the site were conserved and restored. (fig. 2). Conservation and restoration works were undertaken on a large number of recovered stone monuments. These works were financed by the Ministry of Culture of the Republic of Croatia. 


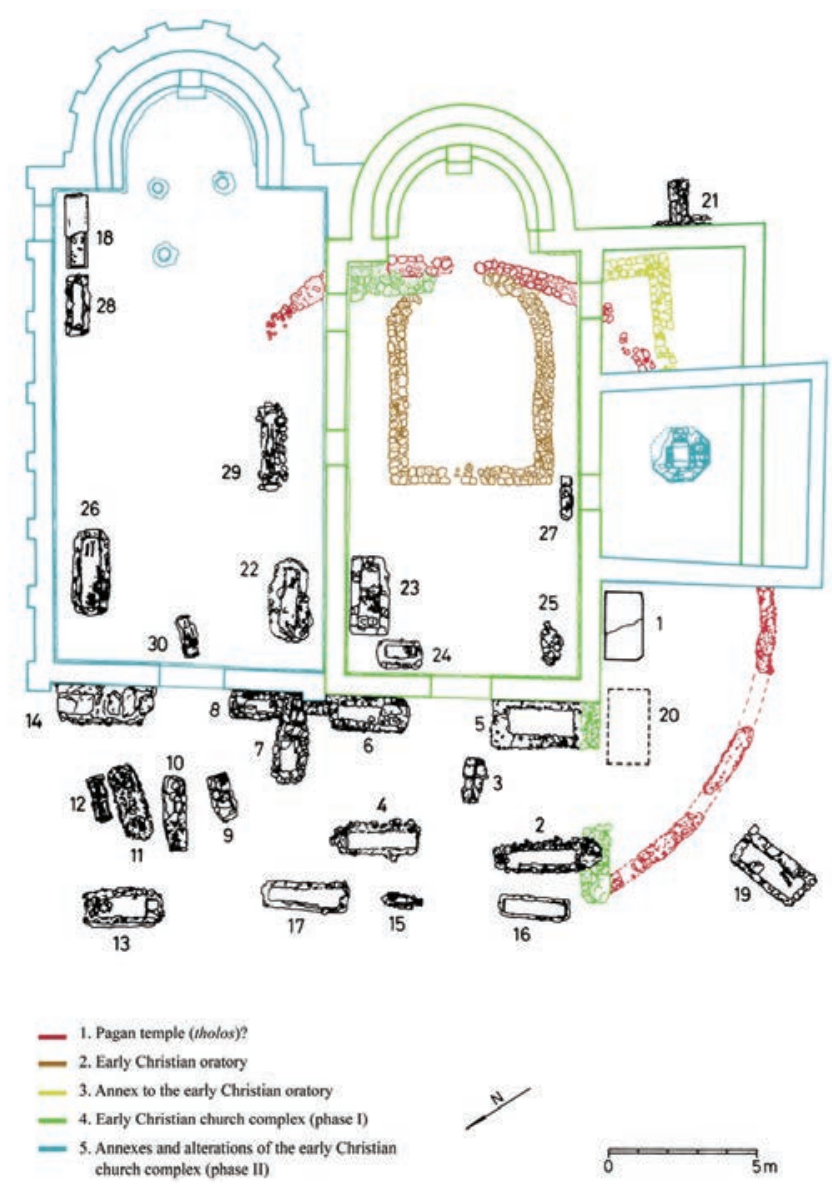

Fig. 3. Ground plan of the site of Glavcine in Podvršje with building phases marked (del. Z. Bakić and M. Grourić)

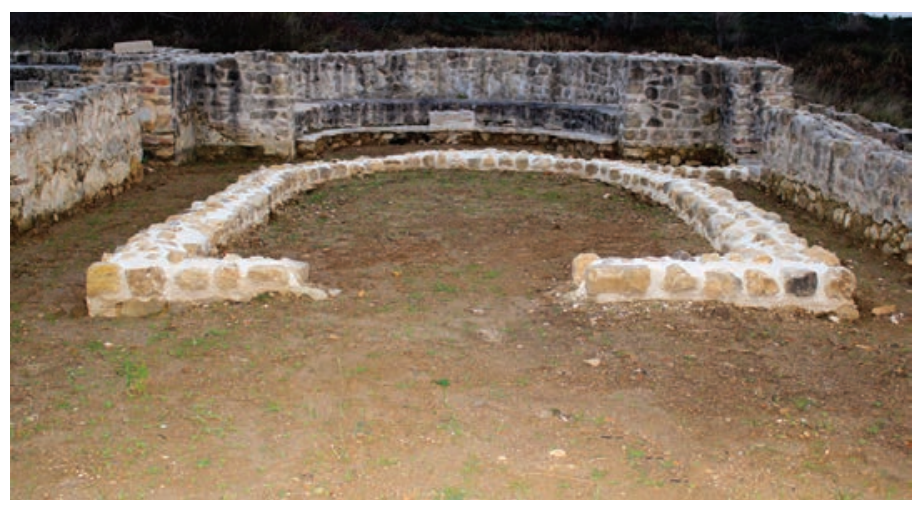

Fig. 4. Podvršje - Glavčine, Early Christian oratory (photo A. Uglešić)

on this floor indicating that the structure may have been destroyed in a fire, which was the reason of its renovation. Monumental architectural fragments reused in chancel screens of the early Christian churches may have belonged to the temple architecture as well as the baldachin columns in their chancels (fig. 9, 22-23). Fragments of monumental architecture from antiquity have been found in graves and excavated soil, particularly on the western side, next to the necropolis. If this actually was a circular temple, it was almost completely torn down prior to building of the first early Christian structure, so that only a portion of circular wall was left and used as an enclosure wall around the newly built structure. Remains of the circular structure were destroyed later, when the churches were built and the necropolis was formed.

Square area may have been situated north of the circular object as indicated by the remains of rammed earth discov-

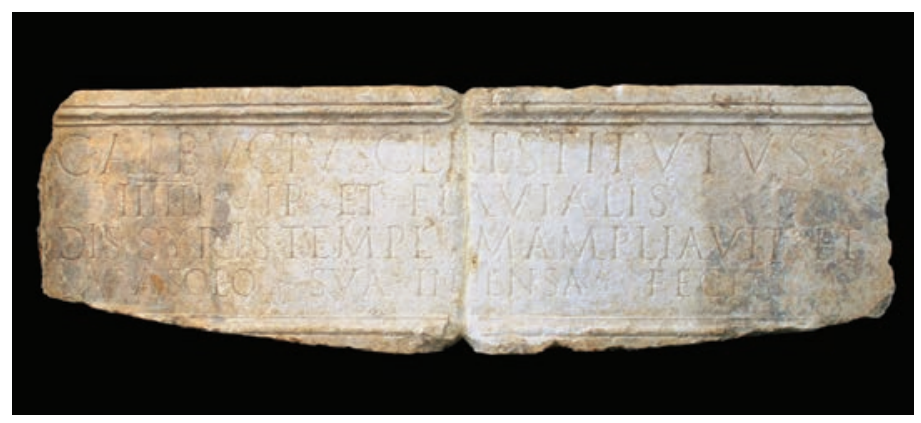

Fig. 5. Inscription about renovation of the Roman temple dedicated to Syrian gods, found as spolium in the tomb, in the memoria (photo A. Uglesicic)

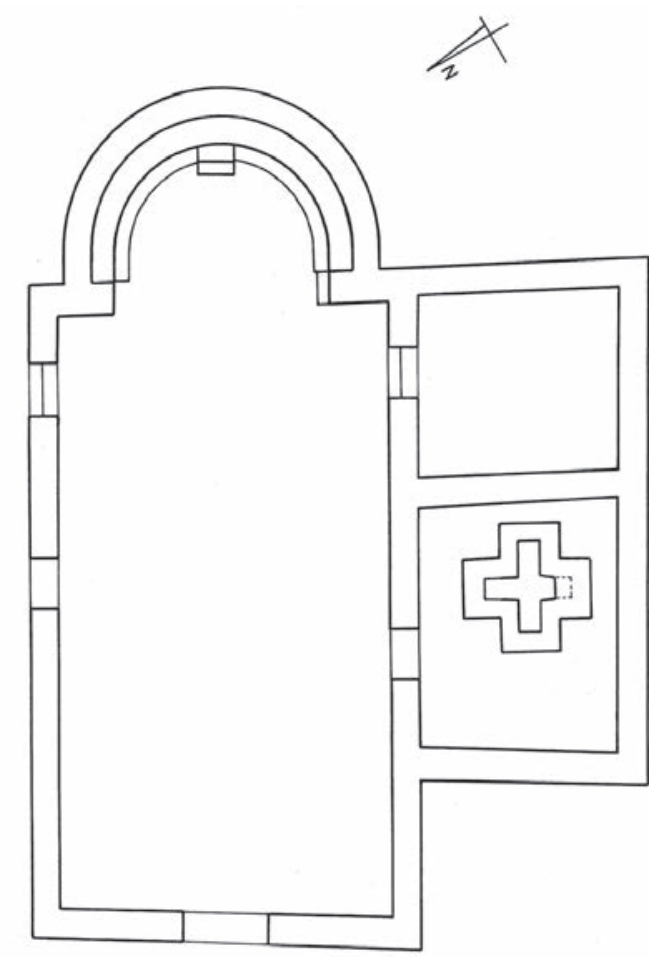

I Faza

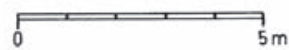

Fig. 6. Ground plan of the church from the 5th c. with a pastophorium and baptistery (del. Z. Bakic)

ered at several spots in probes in the area north and northeast of the early Christian churches during the research campaigns in 2004. Remains of thick rammed earth were found in the agricultural activities preventing deep ploughing and more extensive damage or destruction of the area.

In the circular structure, in the south-eastern part, a smaller structure was built with the following dimensions: length from the front to the middle of the apse 5,4 $\mathrm{m}$ and width 3,5 m (fig. 3-4). It was preserved only in its footing as it was destroyed by subsequent building. Although only pottery was found in the research of this area, the assumption that this was the first Christian structure functioning as oratory is very likely. Small room discovered on its southern side probably belonged to the same or somewhat later phase. Its function cannot be defined precisely for now, but we can assume that it had certain purpose in the first Christian construction (fig. 3).

Southern church was built at the place of the oratory, i.e. around it (fig. 3, 6). The length of that church from the front to the back measures $13,3 \mathrm{~m}$, and its inner width is 


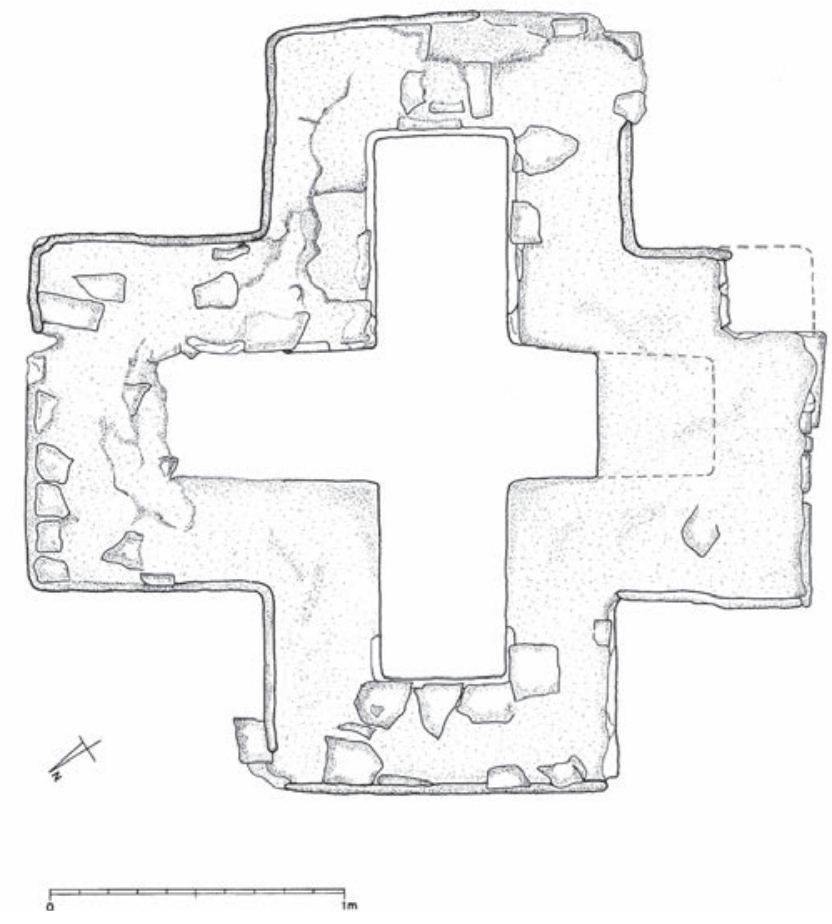

Fig. 7. Baptismal font of the baptistery from the 5th c. (del. Z. Bakic')
25). A bench for priests measuring $45 \mathrm{~cm}$ in width spreads around the apse. The throne or a stool (sedes) made of tegulae is in its middle, for the priest who celebrated mass. A small footstool ( $20 \mathrm{~cm}$ wide) is under the subsellium. We can only hypothesize about the look of the chancel screen. It could have been in shape of an angular letter „U“ but it is also possible that it was placed parallelly, spreading from the northern to the southern lateral wall. A slab of this screen was preserved, incorporated in the floor of the northern church (fig. 15). The floor in the church was made of thick mortar, and its foundations were made of stones arranged vertically. Finds of several impost-capitals in various sizes indicate that there were mullioned windows on the front and lateral walls of the church.

On the southern side of the church, near the apse, is a door ( $0,95 \mathrm{~m}$ wide) leading to a room (pastophorium) on the southern side of the church with dimensions of 3,9 $\mathrm{x}$ 3,5 $\mathrm{m}$ (interior dimensions). This pastophorium (fig. 6), probably diaconicon, was created in the same period as the church and it is organically related to it. The floor of the pastophorium was made of mortar, which was preserved at places. In continuation of the pastophorium is a baptistery whose western wall is slanted in relation to the main axis of the church. The church was connected with the baptistery

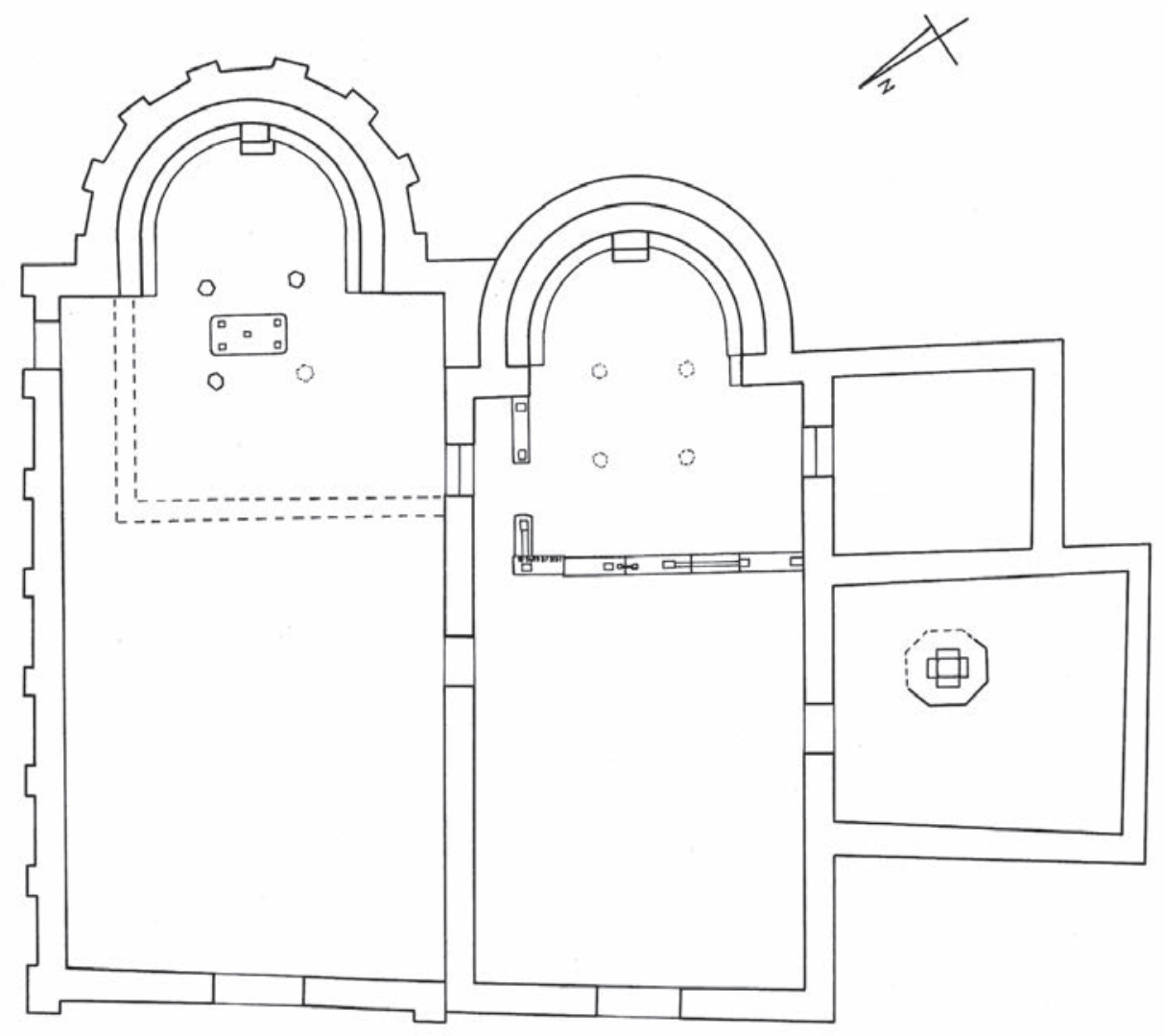

II Faza

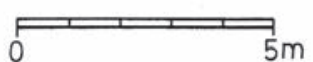

Fig. 8. Ground plan of the Early Christian double churches, 6th c. (del. Z. Bakic')

$6,7 \mathrm{~m}$. Northern longitudinal wall is best preserved of all church walls, and its biggest height was about $0,7 \mathrm{~m}$ (from the floor height). The semicircular, protruding apse is on the eastern side of the church, with inner width of $4,3 \mathrm{~m}$ and depth of $3,3 \mathrm{~m}$. The apse had a window transenna whose remains were found on the eastern side of the church (fig. with a door measuring $0,95 \mathrm{~m}$ in width. Near the eastern side of the baptistery, a baptismal font was made of tegulae in shape of the Greek cross, with arms measuring 2,7 X 2,7 $\mathrm{m}$ (fig. 6-7). Floor of the baptistery consisted of thick layer of mortar, preserved for the most part. 


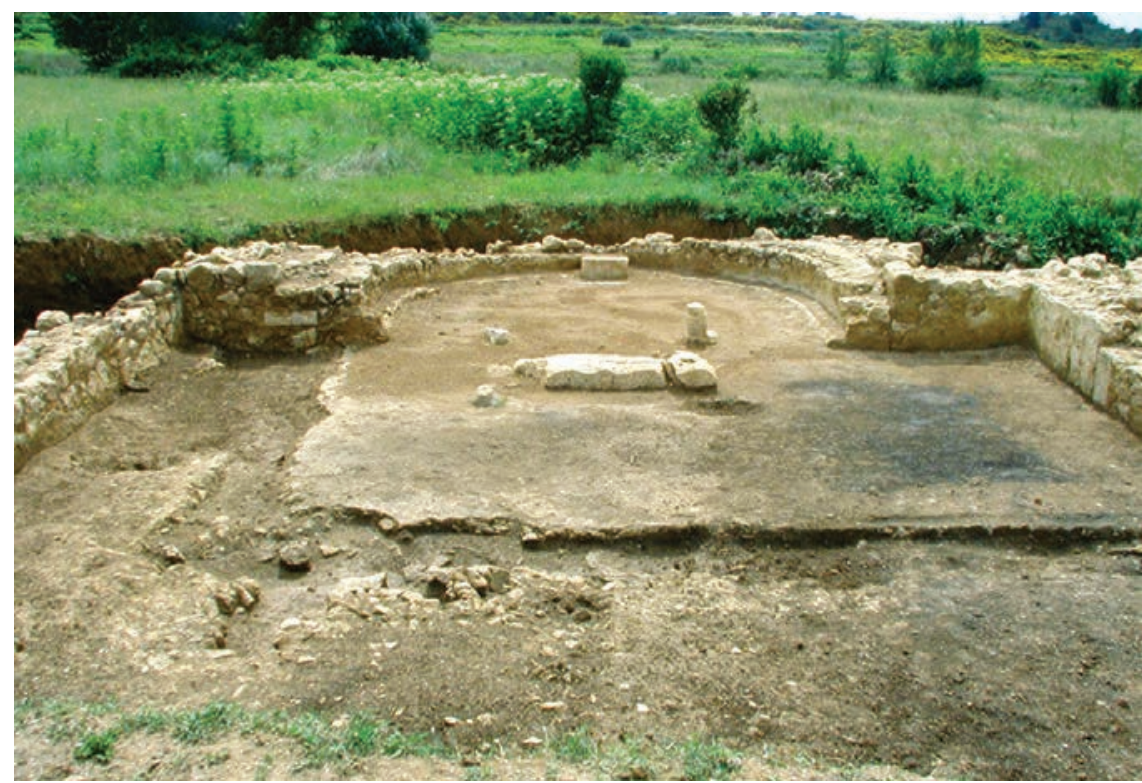

Fig. 9. View of the southern church sanctuary (photo A. Uglesić)

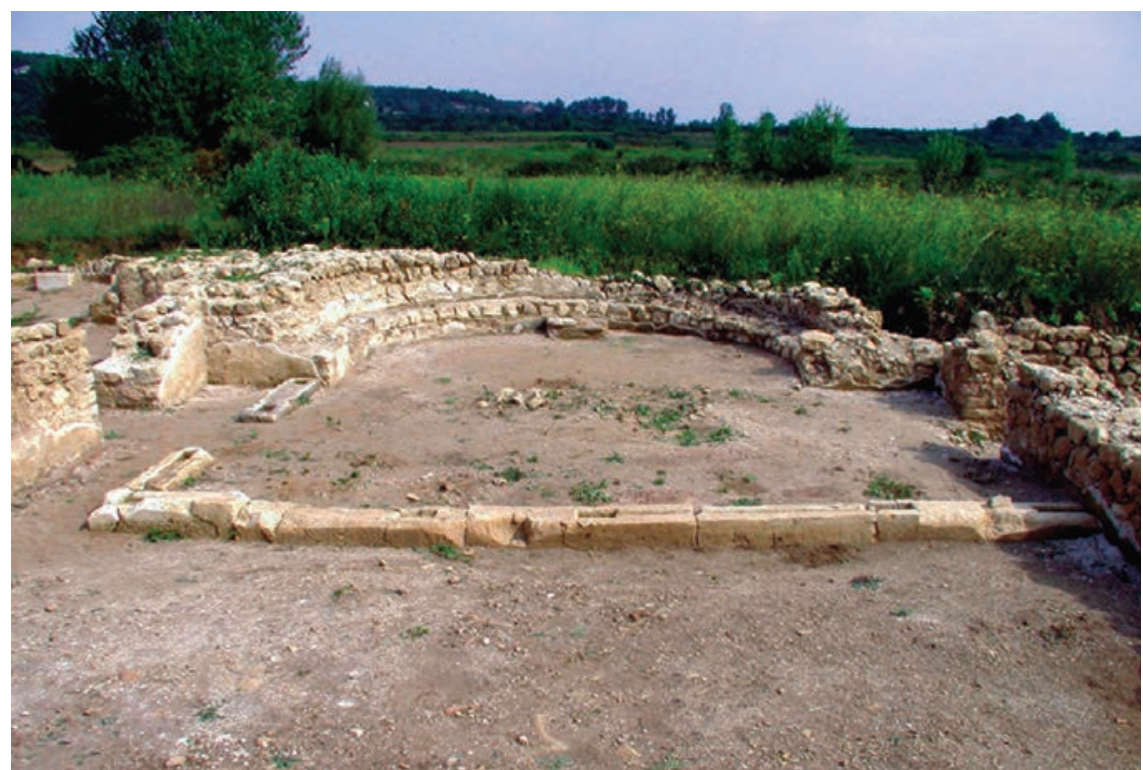

Fig. 10. View of the northern church sanctuary (photo A. Uglesicí)

chapel most likely belonged to the members of his family. The covering slab of the tomb was probably fragment of the stela found in 1939 which ended up in the Museum of Nin Antiquities (fig. 28).

The other, northern church was annexed to the southern church (fig. 3, 8). Northern wall of the southern church became in that way the only joint wall of both churches, and two doors (width $0,95 \mathrm{~m}$ ) on this wall enabled communication between the churches. The southern church had a chancel screen in shape of the letter „L“ (fig. 9). Base of the chancel screen has been completely preserved, that is its ground posts, made of Roman spolia. The screen had eight pilasters with colonnettes and capitals, carved in one piece and five slabs two of which were wider, on the sides of the central entrance to the presbytery, while the remaining three were narrower. Many fragments of slabs and pilasters with colonnettes and capitals were found in the excavations so that some of them can be completely reconstructed (fig. 16-19). Inside the chancel screen was a baldachin, recognizable in numerous fragments of columns with bases with several mouldings, made of Proconnesian marble (fig. 22-23). Post holes of the ciborium columns were defined in the excavations of the chancel. Marble capitals topped the columns (fig. 24). Considering the proportions and characteristics of the column bases, we can assume that they were of earlier date and reused. It is worth mentioning that the marble from the island of Proconnesos in the Sea of Marmara was the cheapest kind of marble in the 4 th century. It was used on the early Christian buildings from the 5 th and 6th centuries in the regions of late antique Istria and Dalmatia, particularly in the early Byzantine period on the cathedral complexes such as Euphrasian basilica in Poreč, St Mary Formosa

On the western side was a chapel (fig. 3) with a monumental tomb made of various Roman spolia (fig. 27), fragments of funerary portrait stela (fig. 28) and mentioned inscription which is particularly important as it offers information on renovation of the temple dedicated to the Syrian gods (fig. 5). Walls of the earlier circular structure were partially used for the chapel, and on the northern side the walls were added to form an entrance. Originally two early Christian sarcophagi probably stood in the chapel, the one found in 1939 and destroyed by a bomb, and another one, discovered in the northern church during the excavations in 2004 (fig. 29). Tomb next to the chapel (G5), built near the church front, belongs to the same group of graves (fig. 3).

The owner of the estate who had the church built was probably buried in the chapel, in the sarcophagus which was subsequently relocated to the northern church chancel. The other sarcophagus and monumental tombs in the in Pula and Basilica Urbana in Salona. ${ }^{9}$

The northern church measured $13,8 \mathrm{~m}$ in length from the front to the back, and its interior width is $7,8 \mathrm{~m}$. Walls of this church were preserved rather evenly, about $40 \mathrm{~cm}$ high in average (from the floor height), having well-preserved plaster at places. The front of this church, as well as of its southern counterpart, was damaged in the works in 1939. Segments of footing were found and only several rows of stones were preserved at places. Protruding apse is on the eastern side of the church. It was semicircular on the inner side, and had shallow lesenes on the outer surface..$^{10}$ Its inner width is $4,4 \mathrm{~m}$, and depth is $3,5 \mathrm{~m}$. Subsellium ( $45 \mathrm{~cm}$ wide) spreads around the apse. A stone throne or a stool (sedes) is in its middle, for the priest who celebrated mass. A small footstool ( $20 \mathrm{~cm}$ wide) is under the subsellium. This church had the chancel screen in shape of the letter „L“, as well as its southern counterpart. The base of the screen was not

${ }_{9}^{9}$ Y. A. MARANO, The circulation of marble in the Adriatic Sea at the time of Justinian, in: Ravenna its role in earlier change and exhange, ed. by J. Herrin and J. Nelson, Institute of Historical Research - University of London - School of Advanced Studies, London 2016, pp. 114, 116-117.

${ }^{10}$ It is worth mentioning that worked stones from the transenne of the northern church were used in the construction of early Croatian graves found in the mound Jokina glavica. Cf. K. GUSAR, Jokina Glavica - ranosrednjovjekovni grobovi, in: Tumuli iz Krneze i Podvršja, p. 51, fig. 3. 


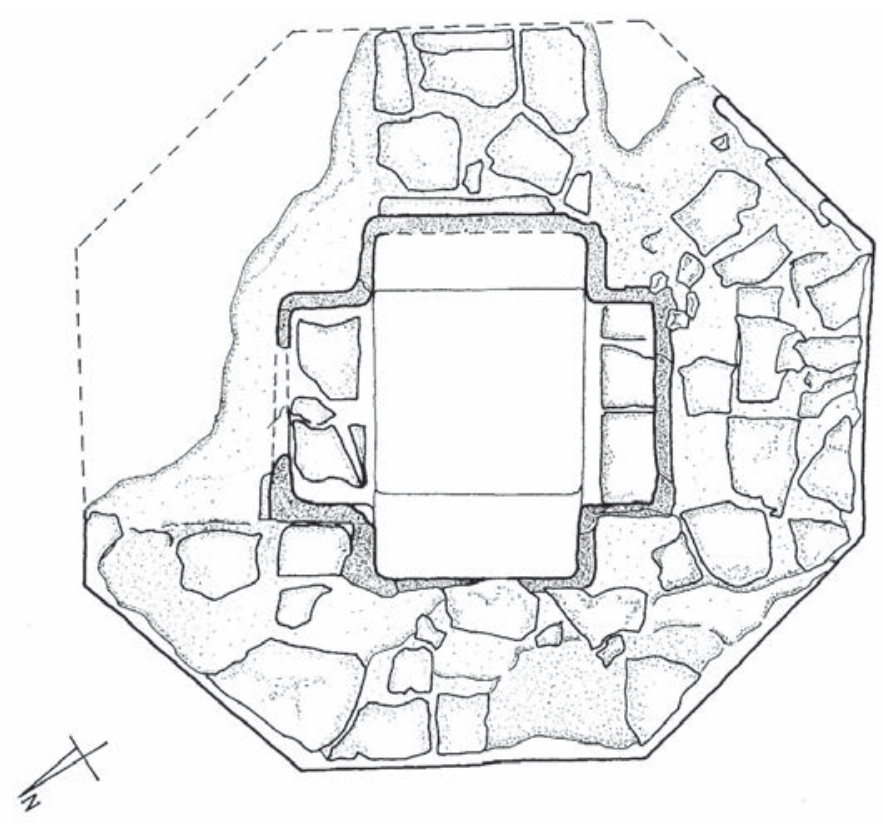

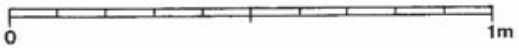

Fig. 11. Baptismal font of the baptistery, 6 th $c$. (del. Z. Bakic')

preserved, but its contours are delineated clearly on the floor (fig. 10) which was made in the similar way as the one in the southern church, only better. The chancel screen could be recognized from the fragments of bases, slabs, and pilasters with colonnettes and capitals. Inside the chancel screen was a baldachin, recognizable from many fragments of its marble columns, and installed bases of three columns were found in their original places in the church chancel (fig. 8, 10). The columns have identical characteristics as the ones in the southern church and they were probably also reused. Under the ciborium was an altar whose base was found as well as several fragments of marble colonnettes (fig. 20-21). An early Christian sarcophagus decorated with a cross which probably stood in the memorial chapel on the southern side of the baptistery was subsequently dug in between the northern part of the chancel screen and northern wall of the church (fig. 3, 29). The church had mullioned windows on the northern lateral wall which is indicated by the find of impost-capital, fallen from the wall after it collapsed (fig. 26). Mullioned window probably decorated the front of the church as well. On the north-eastern part of the church was a door, subsequently walled up, most probably after the mentioned sarcophagus was dug in behind the door.

In the same period when the northern church was built, the baptistery on the southern side was renovated and partially extended. It acquired rectangular form, with dimensions of 4,7-5,7 x 5,7 m (interior dimensions). Baptismal font made of tegulae was incorporated in the former cross-shaped font. Its outer parapet has polygonal form, and it is in shape of the Greek cross on the inside (fig. 8, 11-12). Parapet sides measure from 64 to $72 \mathrm{~cm}$ and they are partially damaged. The cross arms measure $72 \times 75 \mathrm{~cm}$. Hydraulic mortar was preserved relatively well on the bottom and lateral sides of the baptismal font.

Dating of the early Christian complex in Glavčine in Podvršje is based largely on the movable archaeological

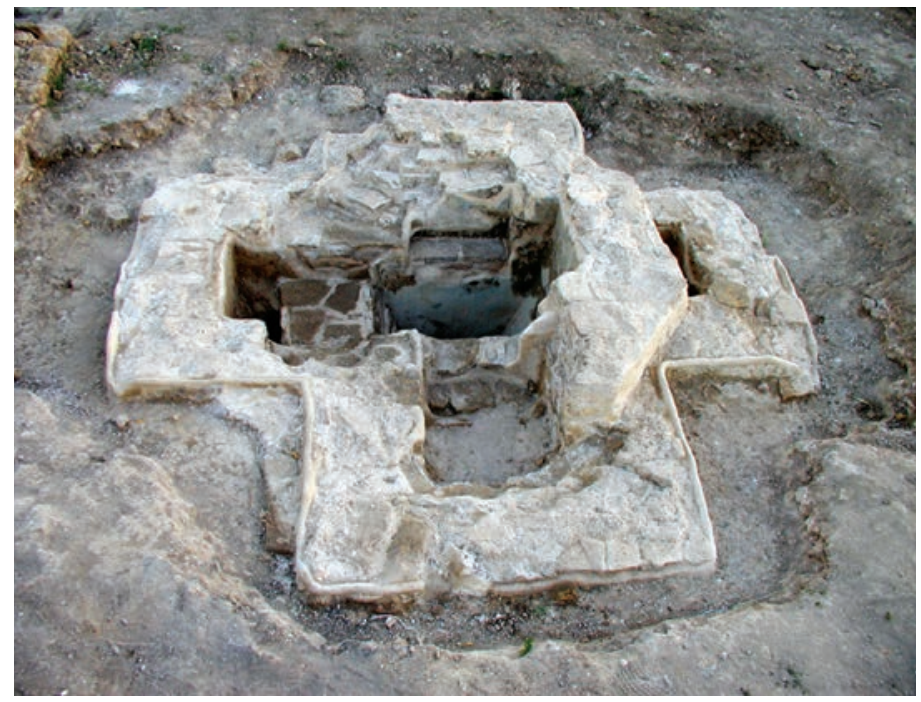

Fig. 12. Two phases of the baptismal font (5th and 6 th c.), after conservation (Photo A. Uglesicí)

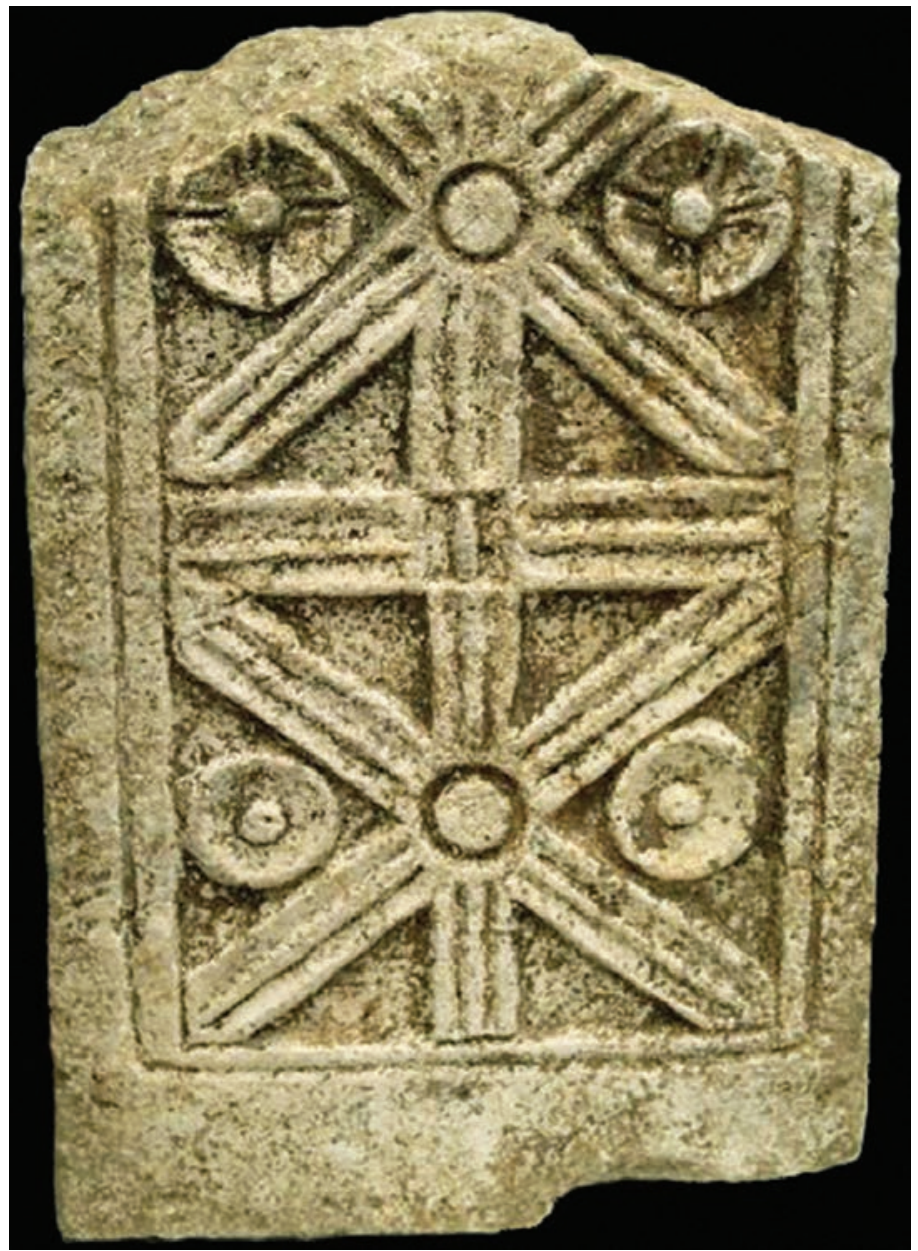

Fig. 15. Chancel screen slab from the southern church sanctuary, 5th $c$. (photo A. Uglešić)

finds. On the basis of the pottery sherds recovered during the oratory excavations, formation of that object can be dated to the first half of the 5 th century. The southern church, pastophorium (diaconicon) and baptistery with the cross-shaped baptismal font on its southern side were built most likely in the middle or during the second half of the 5 th century. That is also when the chapel on the eastern side of the baptistery was made. The northern church features early Byzantine stylistic characteristics so it can be dated to the time of Justinian, from 530 s to 560 os. In that period the 

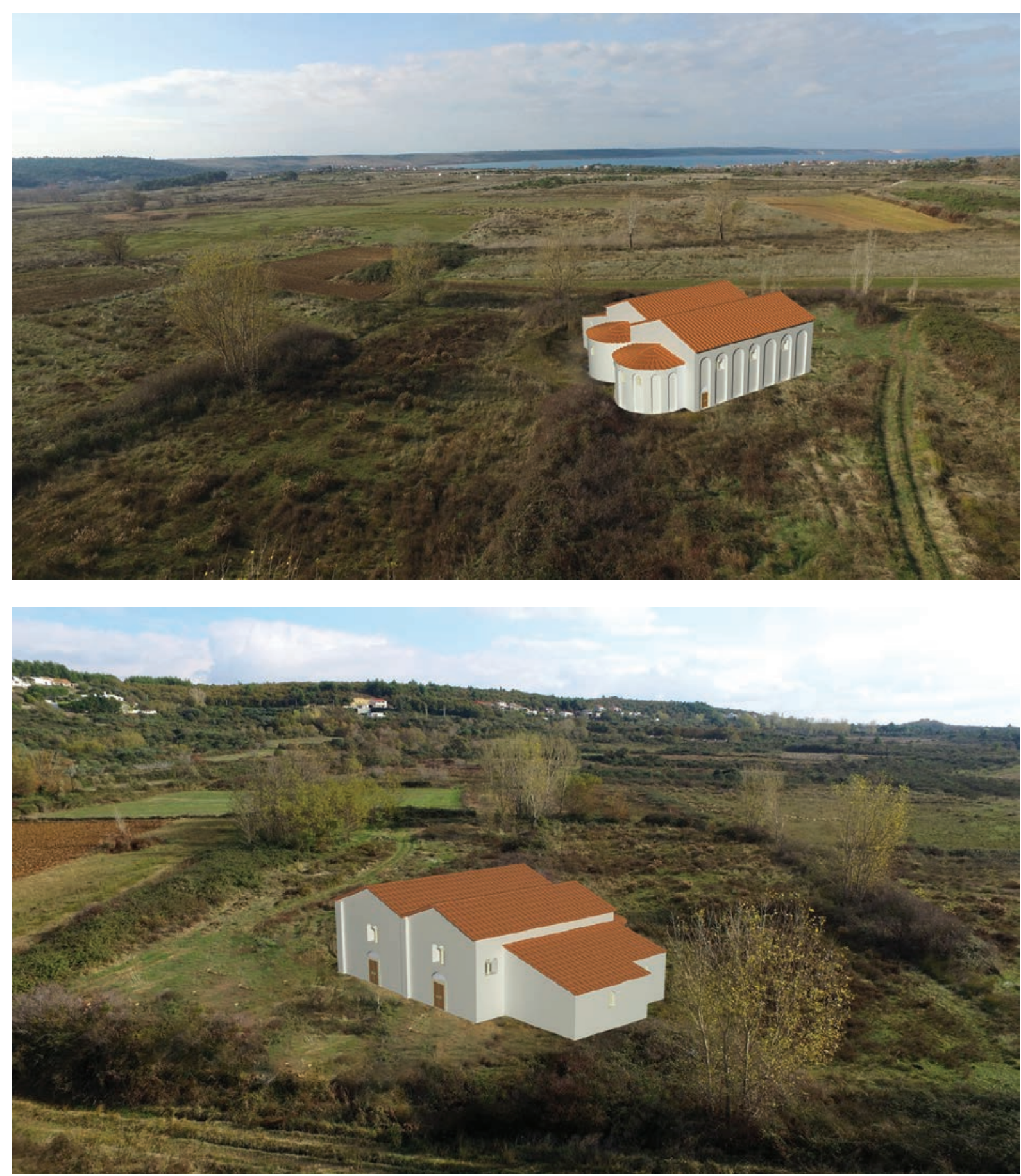

Fig. 13.-14. 3D reconstruction of the appearance of the double Early Christian churches in Podvršje (del. D. Vujević)

baptistery was renovated and partially extended and former cross-shaped baptismal font was altered into a font whose enclosing parapet has polygonal form and the shape of the Greek cross on the inside.

The cemetery was found on the western side of the churches' front. Six graves were found in the northern church including a burial in sarcophagus. There were four burials in the southern church. One grave was found on the western side of the memorial chapel, and another one on the eastern side of pastophorium. Total of 30 graves were found (fig. 3). Graves on the western side of the churches' front are mostly arranged in more or less regular rows. On the whole these are typical examples of late antique graves, stone sarcophagi, walled tombs and graves under teguale, and two infant burials in amphorae. Only four graves yielded finds. A "Mediterranean" type buckle made of silver was found in grave 3 (fig. 30), , pair of golden earrings in grave 14 (fig. 31),,$^{12}$ cross-shaped silver fibula in grave 16

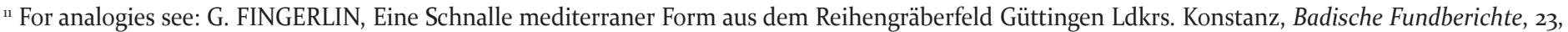
Freiburg 1967, pp. 159-184; Z. VINSKI, Kasnoantički starosjedioci u salonitanskoj regiji prema arheološkoj ostavštini predslavenskog supstrata, Vjesnik za arheologiju i historiju dalmatinsku, LXIX (1967), Split 1974, pp. 5-98. Almost identical buckle was found in grave 279 of necropolis Kranj - Laih in Slovenia. Cf. V. STARE, Kranj, nekropola iz časa preseljevanja ljudstev (= Katalogi in monografije, 18), Narodni muzej v Ljubljani, Ljubljana 1980, p. 70, T. 83.10).

${ }^{12}$ Typologically identical examples of earrings were found in Italy, at the sites of Santa Lucia di Notaresco, Teramo (cf. A. R. STAFFA, Un quadro di riferimento per Castel Trosino: presenze longobarde fra Marche ed Abruzzo, in: La necropoli di Castel Trosino, Silvana Editoriale, Milano 1995, pp. 110-111, fig. 6o, 27919-27920) and in Rome on Palatine, Vigna Barberini, gr. 1 (G. RIZZO, M. VITALE, Palatino, Vigna Barberini, in: Roma, Dall'antichità al medioevo, Archeologia e storia nel Museo Nazionale Romano Crypta Balbi, Electa, Milano 2012, pp. 231-234, fig. I.12.3, I.12.3c). 


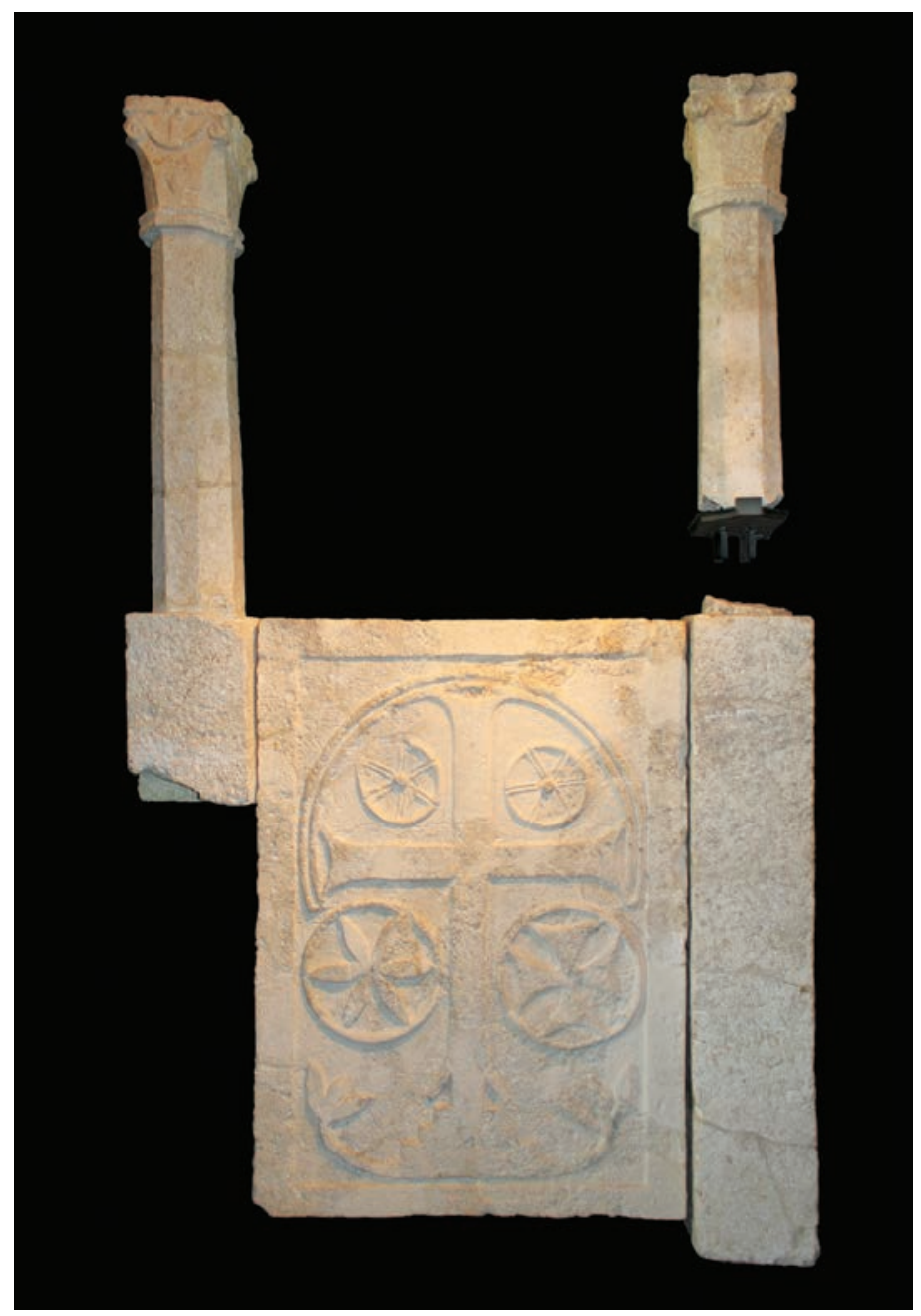

Fig. 16. Slab with depiction of Golgotha and pilasters with small columns (on display in the Archaeological Museum in Zadar). Photo A. Uglešić

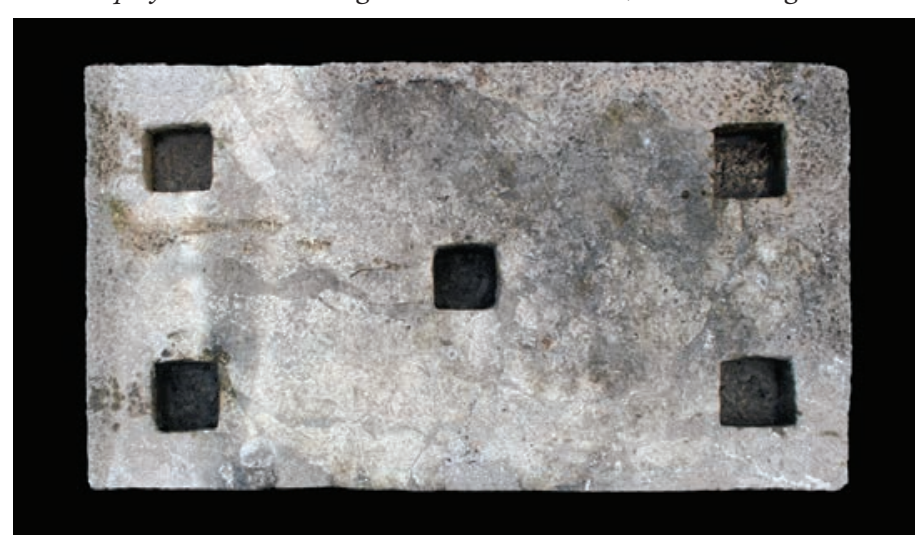

Fig. 20. Base of the northern church altar (photo A. Uglesicic)

(fig. 32), ${ }^{13}$ and fish-shaped iron fibula was found in grave 22 (fig. 33). Mentioned finds can be dated broadly from the second half of the 6 th to the first half of the 7 th century on the basis of their characteristics. An interesting find from
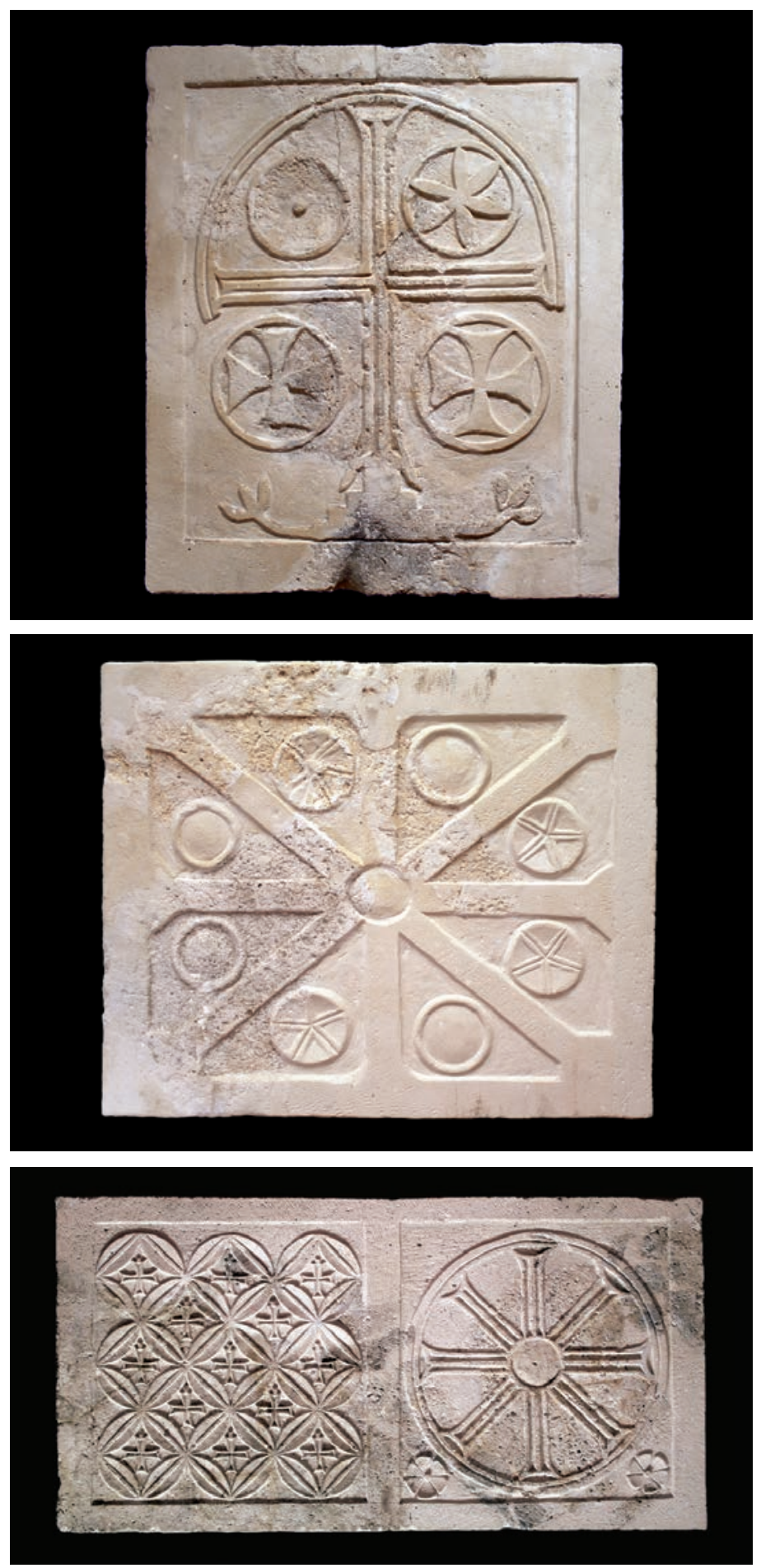

Fig. 17.-19. Reconstructed slabs of the chancel screen (photo A. Uglesicic)

grave 14 is the covering slab with deeply incised Latin cross facing the inner side, i.e. the deceased person (fig. 31c). ${ }^{14}$

Radiocarbon analysis $\left({ }^{14} \mathrm{C}\right)$ of osteological remains was made for four graves. ${ }^{15}$ Grave 22 was dated to the chronological range from 430 to $605,{ }^{16}$ grave 25 from 430 to $580,{ }^{17}$

${ }^{13}$ For analogies see: Z. VINSKI, Krstoliki nakit epohe seobe naroda u Jugoslaviji, Vjesnik Arheološkog muzeja u Zagrebu, 3. s., III, Zagreb 1968, pp. 103-151; R. JURIĆ, Fibula oblika križa iz Podgrađa (Asseria) kod Benkovca, Diadora, 21, Zadar 2003, pp. 213-226.

${ }^{14}$ A similar example of this type of slab was incorporated as spolia in the church of St George in Kruševo near Obrovac. Cf. J. VUČIĆ, Arheološka istraživanja kod crkve sv. Jure u Kruševu, Diadora, 24, Zadar 2011, T. 10.29.

${ }^{15}{ }^{14} \mathrm{C}$ analysis of the samples from graves 22, 25 and 26 was carried out in the Beta Analytic Radiocarbon Dating Laboratory (Miami, USA), and of the sample from grave 29 in Poznań Radiocarbon Laboratory (Poznań, Republic of Poland).

${ }^{16}$ Calibrated result (95\% probability): Cal AD 430 to 490 (Cal BP 1520 to 1460); Cal AD 510 to 515 (Cal BP 1440 to 1435); Cal AD 530 to 605 (Cal BP 1420 to 1345 ). Calibrated result (68\% probability): Cal AD 540 to 575 (Cal BP 1410 to 1375 ).

${ }^{17} 2 \sigma$ calibrated result (95\% probability): Cal AD 430 to 580 (Cal BP 1520 to 1370). $1 \sigma$ calibrated result (68\% probability): Cal AD 440 to 490 (Cal BP 1510 to 1460); Cal AD 510 to 520 (Cal BP 1440 to 1430); Cal AD 530 to 550 (Cal BP 1420 to 1400). 


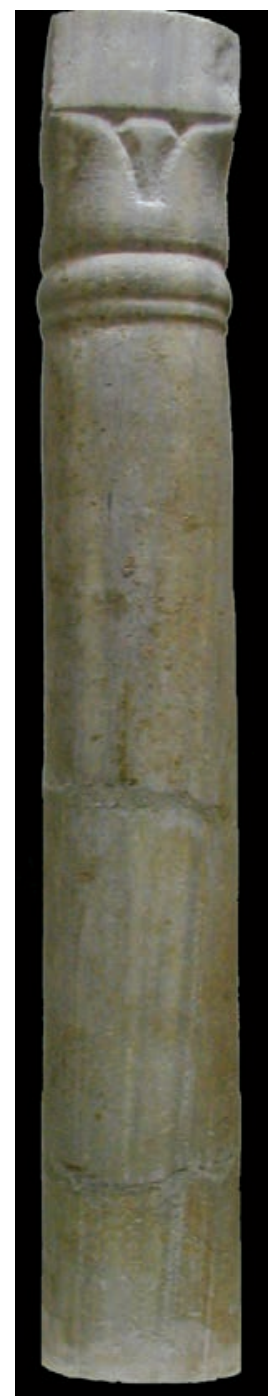

Fig. 21. Small marble column of the northern church altar (photo A. Uglešić)

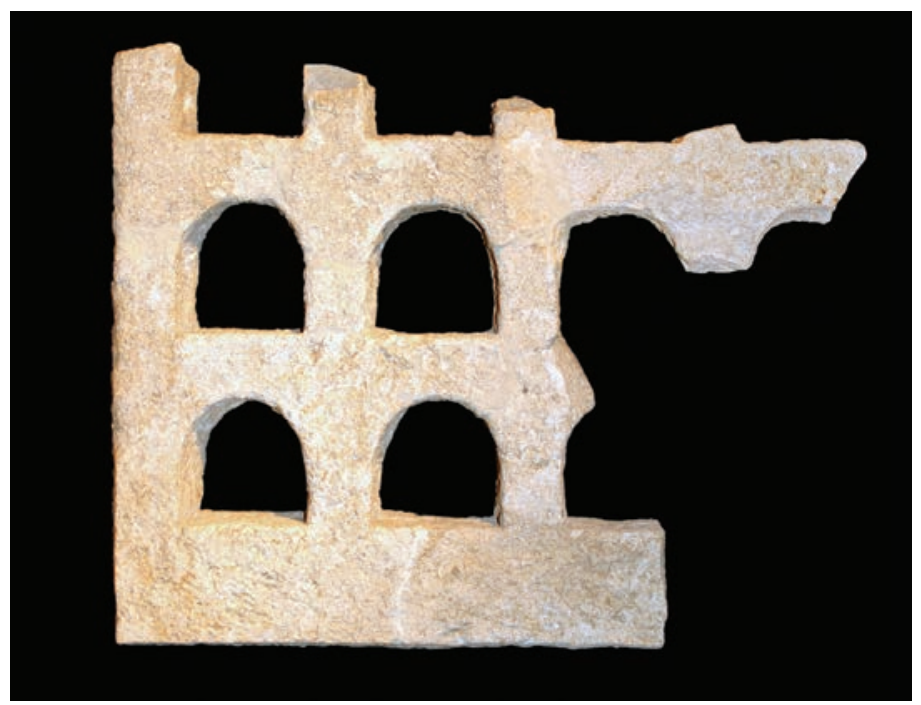

Fig. 25. Transenna fragment (photo A. Uglešić)

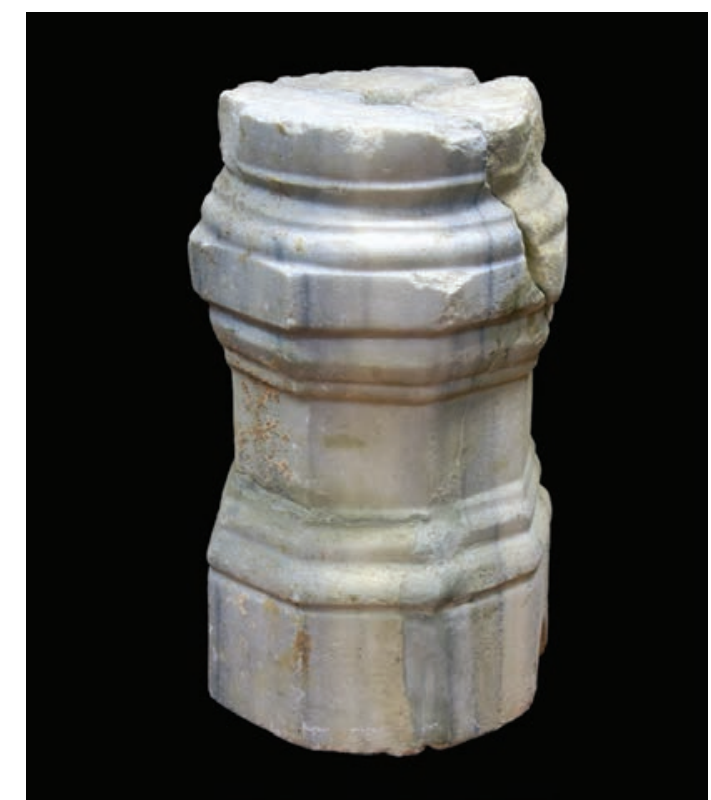

Fig. 22. Marble baldachin base (photo A. Uglešić)

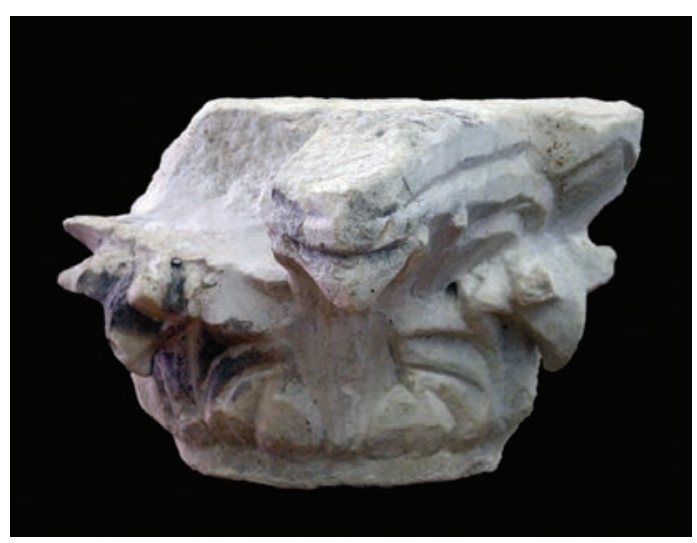

Fig. 24. Marble baldachin capital (photo A. Uglesicí)

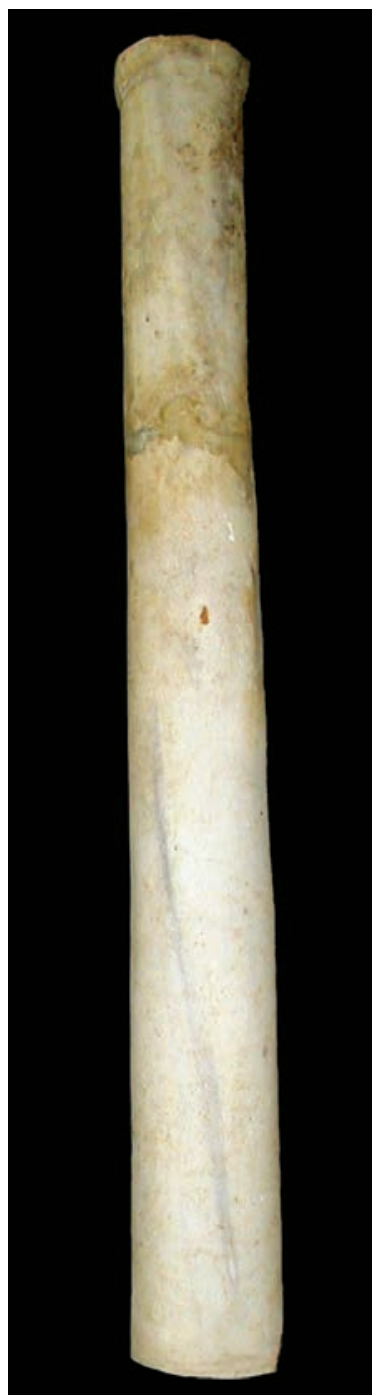

Fig. 23. Marble baldachin column (photo M. Parica)

and grave 26 from 440 to $600 .{ }^{18}$ Only one grave (G29) stands out among all graves regarding its manner of construction. It was built in drystone wall technique, and it was subsequently dug in the northern church floor. Radiocarbon analysis of the bones of the deceased person dated it to the early medieval period, more precisely chronological range from 692 to $887 . .^{19}$

Over 800 pieces of different movable stone fragments from the Roman and Early Christian period have been found in the excavations at the site of Glavčine. Fragments of church stone furnishings and decorative architectural fragments are most significant finds from the Early Christian period. Some of them conjoin enabling reconstruction of the interior and exterior of the churches (fig. 13-14). Several hundreds of window glass fragments were found as well as a large number of fragments of various early Christian glass vessels. These are mostly fragments of oil lamps, one of which is exceptionally rare (biconical form with three lugs) (fig. 34). ${ }^{20}$ Metal finds comprise mostly iron nails.

\footnotetext{
${ }^{18} 2 \sigma$ calibrated result (95\% probability): Cal AD 440 to 490 (Cal BP 1510 to 1460 ); Cal AD 510 to 520 (Cal BP 1440 to 1430 ); Cal AD 530 to 600 (Cal BP 1420 to $1350)$. $1 \sigma$ calibrated result ( $68 \%$ probability): Cal AD 540 to 580 (Cal BP 1410 to 1370 ).

${ }_{19}^{19} 68,2 \%$ probability: $726 \mathrm{AD}$ - $738 \mathrm{AD}$ (7,3\%), $768 \mathrm{AD}$ - $779 \mathrm{AD}$ (7,9\%), $789 \mathrm{AD}-870 \mathrm{AD}$ (53\%). 95,4\% probability: $692 \mathrm{AD}-748 \mathrm{AD}$ (20,9\%), $762 \mathrm{AD}$ - 887 AD (74,5\%).

${ }^{20}$ Š. PEROVIĆ, Reperti di vetro nel complesso paleocristiano di Podvršje (Croazia), in: Il vetro in Italia: testimonianze, produzioni, commerzi in età basso medievale. Atti XV Giornate Nazionali di Studio sul Vetro A.I.H.V. (= Ricerche Collana del Dipartimento di Archeologia e Storia delle Arti, VII), Università della Calabria, Arcavacata di Rende 2012, pp. 594-595, fig. 6.
} 


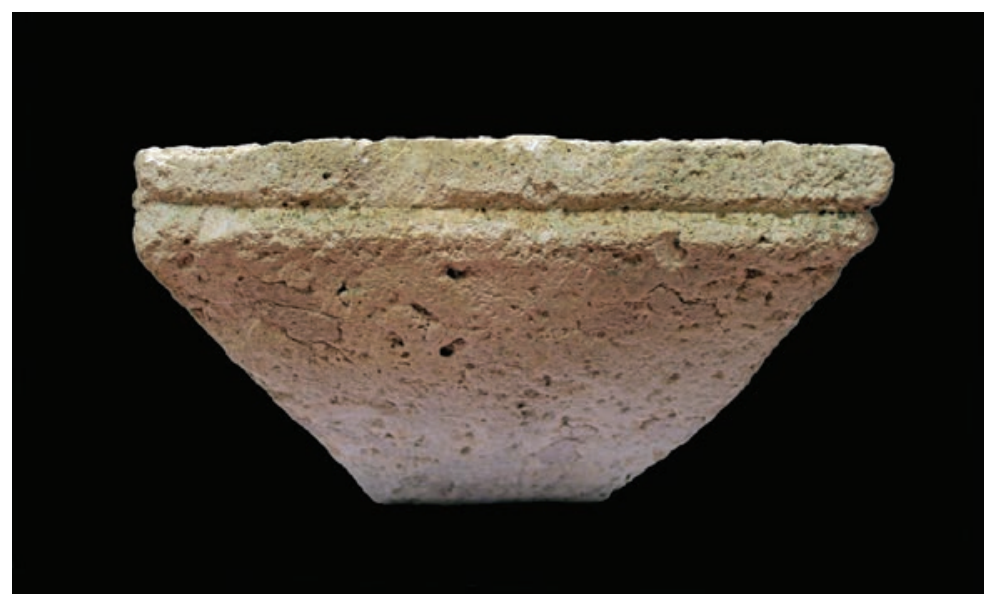

Fig. 26. Impost-capital of two-mullion windows (photo A. Uglesicí)

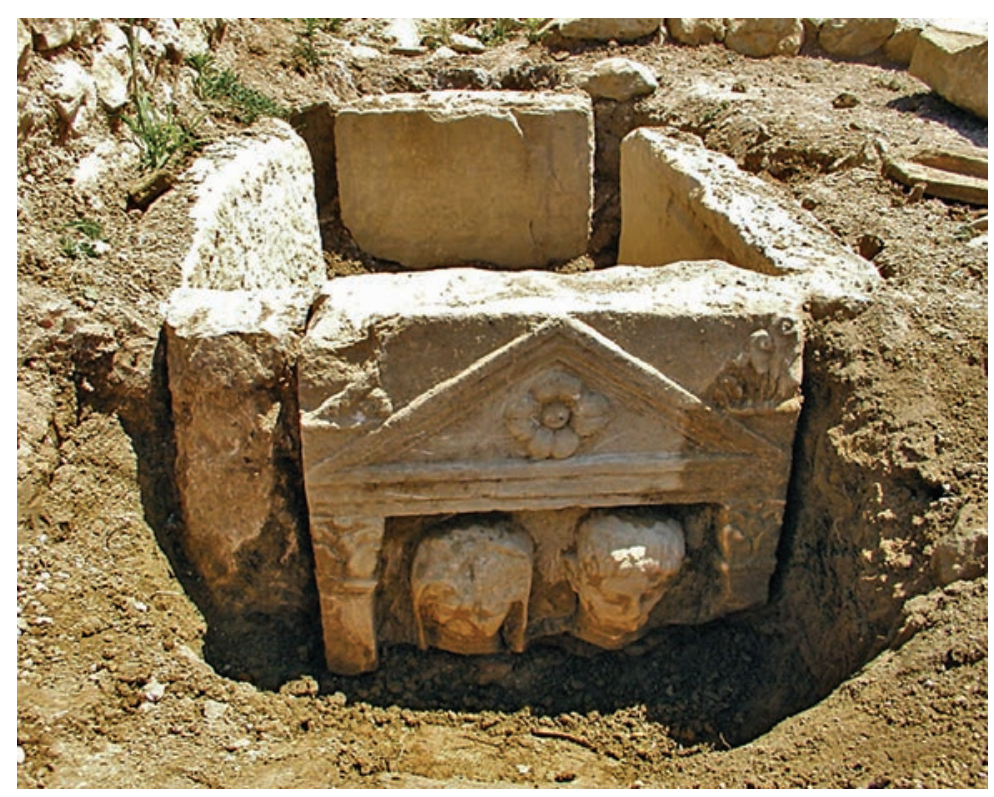

Fig. 27. Monumental tomb in the memoria made of Roman spolia (photo A. Uglešić)

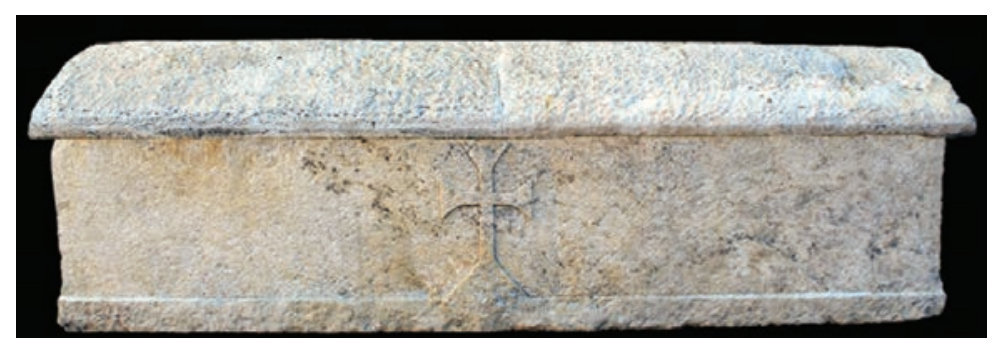

Fig. 29. Early Christian sarcophagus decorated with a cross, found next to the northern church sanctuary (photo A. Uglesić)

There was also one iron knife, four Roman bronze fibulae, and seven examples of Roman coins from the 2 nd, 3 rd and 4th centuries. Sherds of ceramic vessels make the most abundant group of finds, dating from early antiquity to the Early Croatian period.

\section{CONCLUSION}

Formation of the complex of geminae with cemetery in Glavčine in Podvršje should be associated with a large Roman estate (villa), which was probbaly accompanied by a settlement (vicus?), remains of which can be found north and east of the early Christian sacral complex. Such

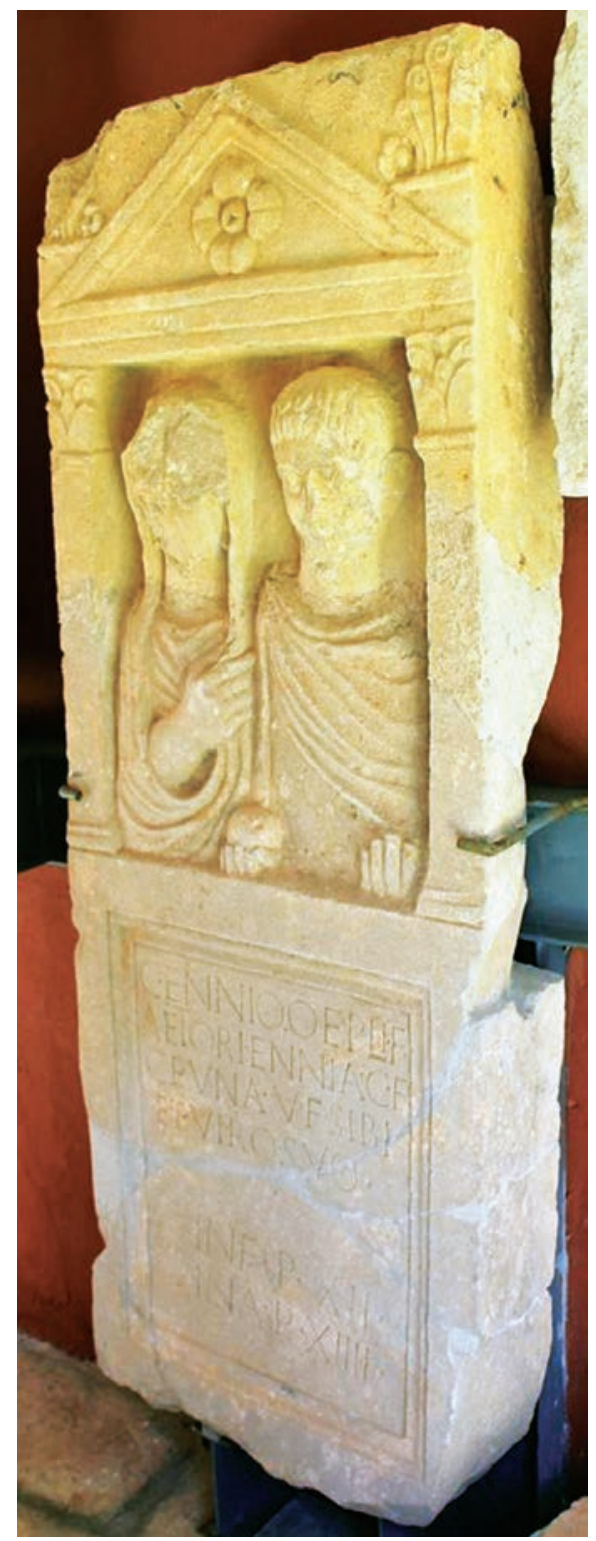

Fig. 28. Roman stela from Poduršje on display in the collection of stone monuments of the Museum of Nin Antiquities (photo A. Uglesicí)

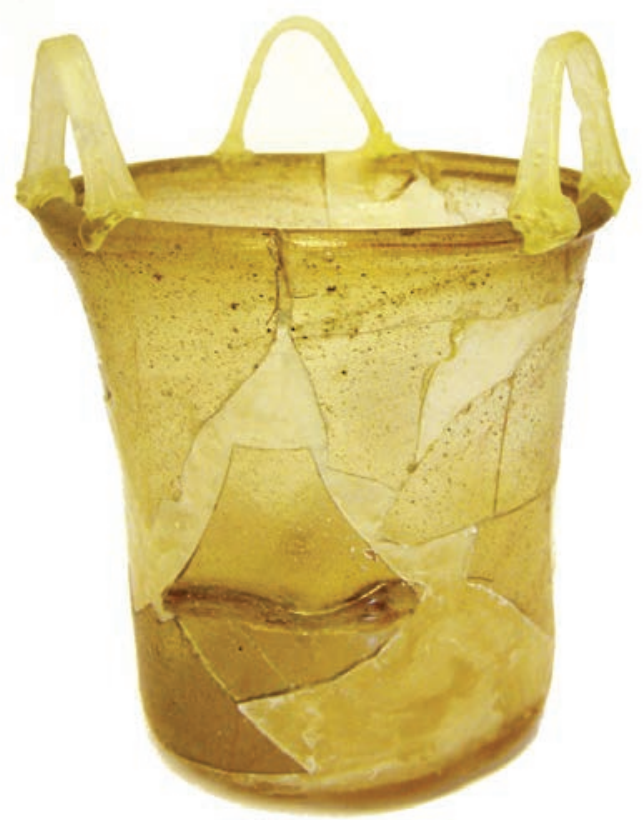

Fig. 34. Biconical three-spout oil lamp (photo Š. Perović) 

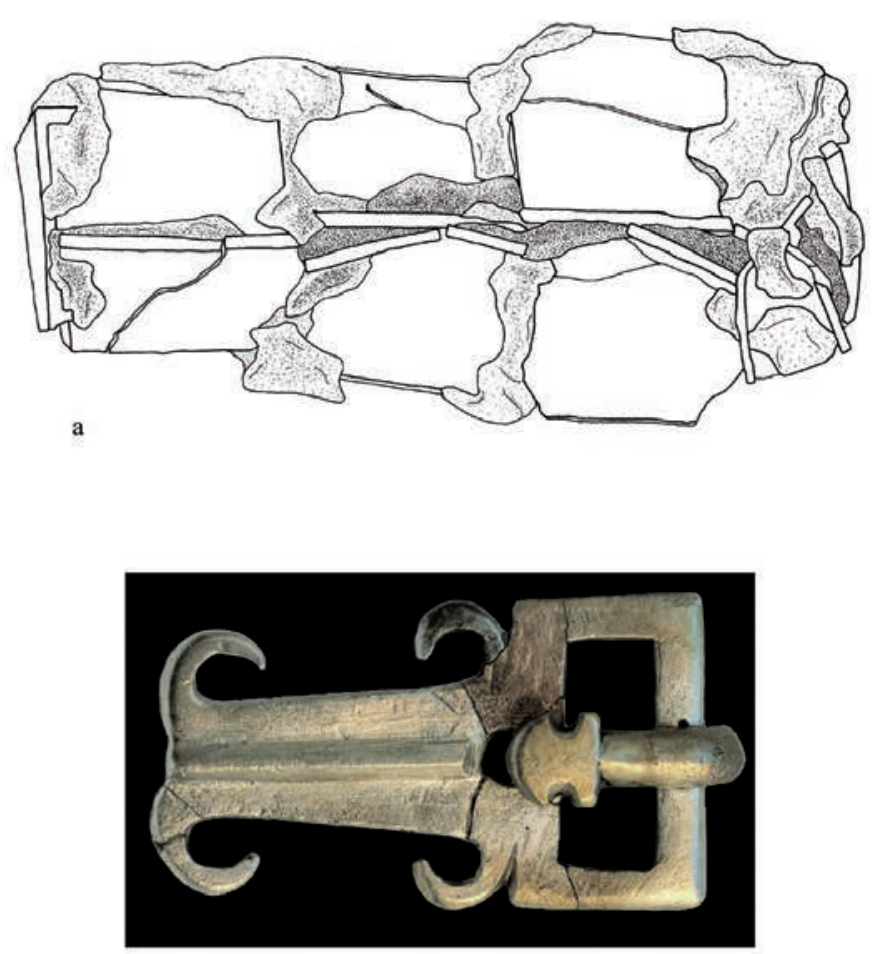

c

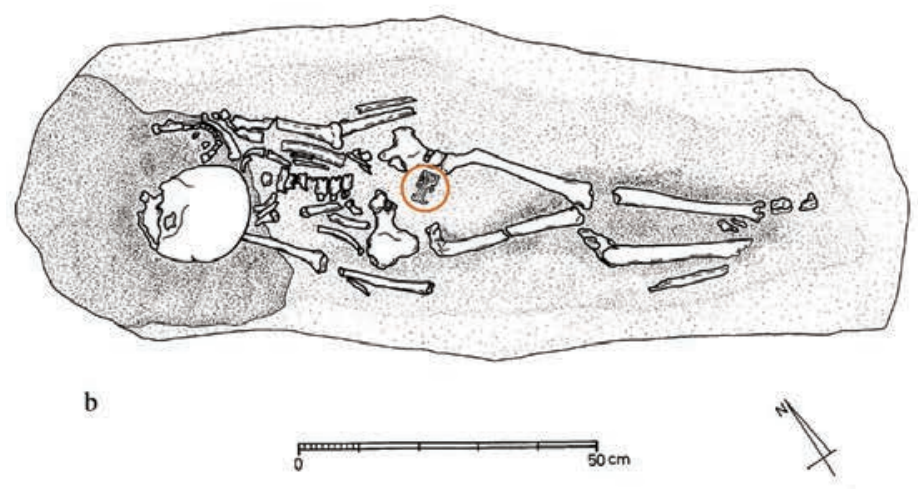

Fig. 30. Grave 3 (a-b) with the find of a "Mediterranean-type" buckle (c). Drawings: Z. Bakić, photo: Z. Alajbeg

large churches with elaborate stone church furnishings and decorative architectural details may have been raised only by a vital economic community. Wealth of the Podvršje area in antiquity was based on exceptionally fertile soil, fishing, pottery production, and primarily large saltworks located in the region of present-day Ljubač whose remains are located in the area of the Ljubač Bay, i.e. on the big beach spreading from Ljubački Stanovi to Ljubač. There were large saltworks also north of Ljubač, in the Plemići Bay. These saltworks were used until the Late Middle Ages, and they were among the largest Roman saltworks on the Croatian side of the Adriatic. After the arrival of the Croats to these regions they probably fell to the Croatian rulers and became a basis of economic power of the early medieval Croatian state.

Geminae in Glavčine in Podvršje were used for a relatively brief period. They were completely destroyed in a fire, as
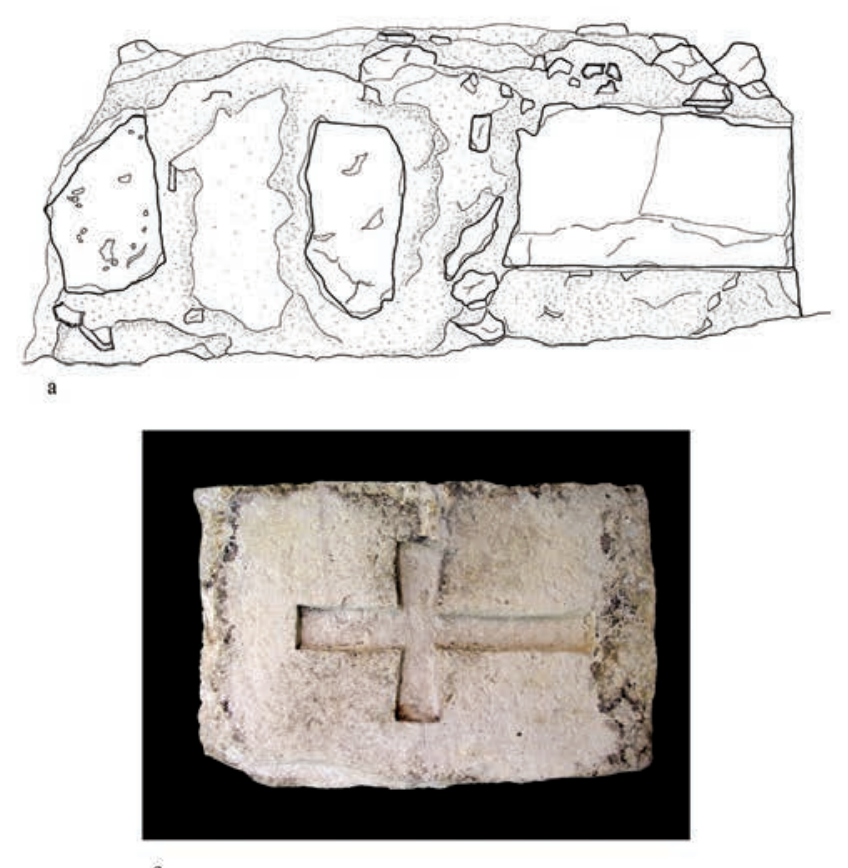

c

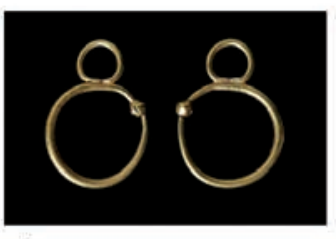

d

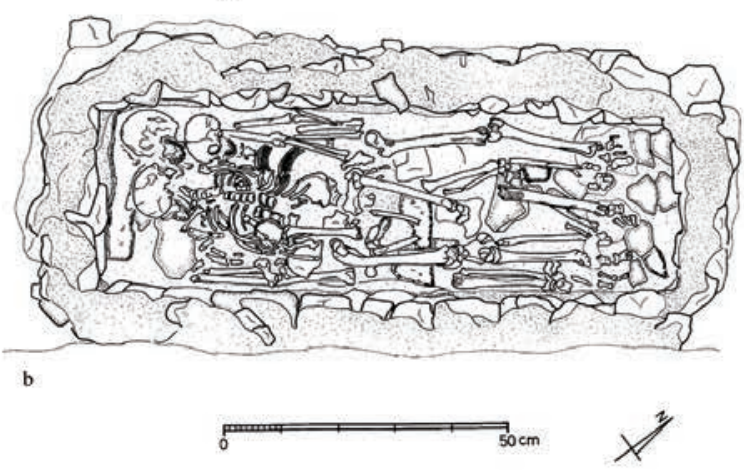

Fig. 31. Grave 14 (a-b) with a deeply engraved Latin cross on the lid (c) and the find of golden earrings (d). Drawings: Z. Bakić, photos: A. Uglesici

confirmed by the remains of the soot layer from 15 to 20 $\mathrm{cm}$ thick. ${ }^{21}$ This probably happened when the Slavs/Croats started coming to these regions, during the 7 th century. As the churches were situated next to the road leading to Nin (Aenona), they were probably intentionally burned down as the most dominant and most monumental objects in the area. Settling of the Slavs/Croats in the wider region of present-day Podvršje and Ljubač happened after these raids, and their settlements were formed in the area of modern villages of Podvršje, Ljubač, Ljubački stanovi and Krneza, where early Croatian graves were found, on the mounds Jokina glavica and Duševića Glavica in Krneza, Matakova glavica in Podvršje, and on prehistoric mounds on Ljubačka kosa. ${ }^{22}$ Finds of ceramic vessels from the site of Glavčine indicate that the Slavs/Croats occasionally lived in the ruins of burnt churches as testified by remains of several hearths

\footnotetext{
${ }^{21}$ Radiocarbon and Tritium Laboratory, Division of Experimental Physics of the Ruđer Bošković Institute made the radiocarbon analysis of charcoal samples from the northern church floor. ${ }^{14} \mathrm{C}$ age (BP): $1485 \pm 90$. Calibration range (\% probability): AD $430-520 \mathrm{AD}(14,7 \%)$, AD 530 - 66o AD (53,5\%). Absolute age in years was calculated from the year 1950, with deviation of 10 , and conventionally accepted half-life of isotope ${ }^{14} \mathrm{C}$ of 5570 years.

${ }^{22}$ Cf. mentioned works by B. MARIJANOVIĆ, K. GUSAR and D. VUJEVIĆ in note 3.
} 

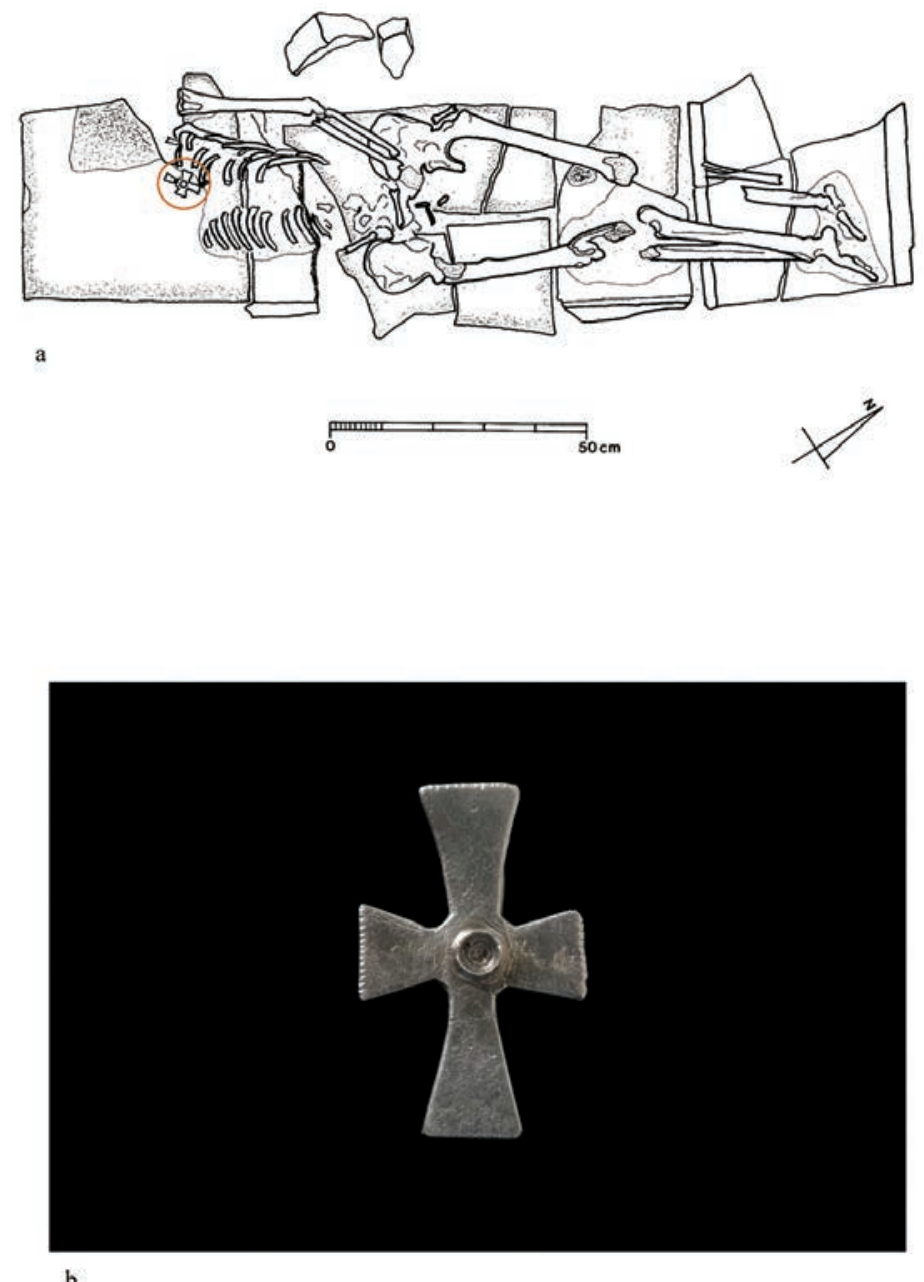

Fig. 32. Grave 16 (a) with the find of cruciform fibula (b). Drawing: Z. Bakic, photo: Z. Alajbeg

on the western side of the churches as well as closing of the doors on their walls with drystone wall. Most finds of medieval pottery were uncovered in the front part of northern church. ${ }^{23}$ Mentioned burial in the northern church (grave 29) belongs to the early Croatian peiod as well as the Byzantine gold coin of Constantine V and Leo IV (76o - 775), found north of the church complex, on the old road which was also probably used in the Roman period. ${ }^{24}$

It is reasonable to expect new finds of early Christian churches in the wider Ljubač region. Such potential site is primarily Ljubljana hillfort, i.e. medieval Castrum Liube where a mighty fort was built in the Justinian's period. This
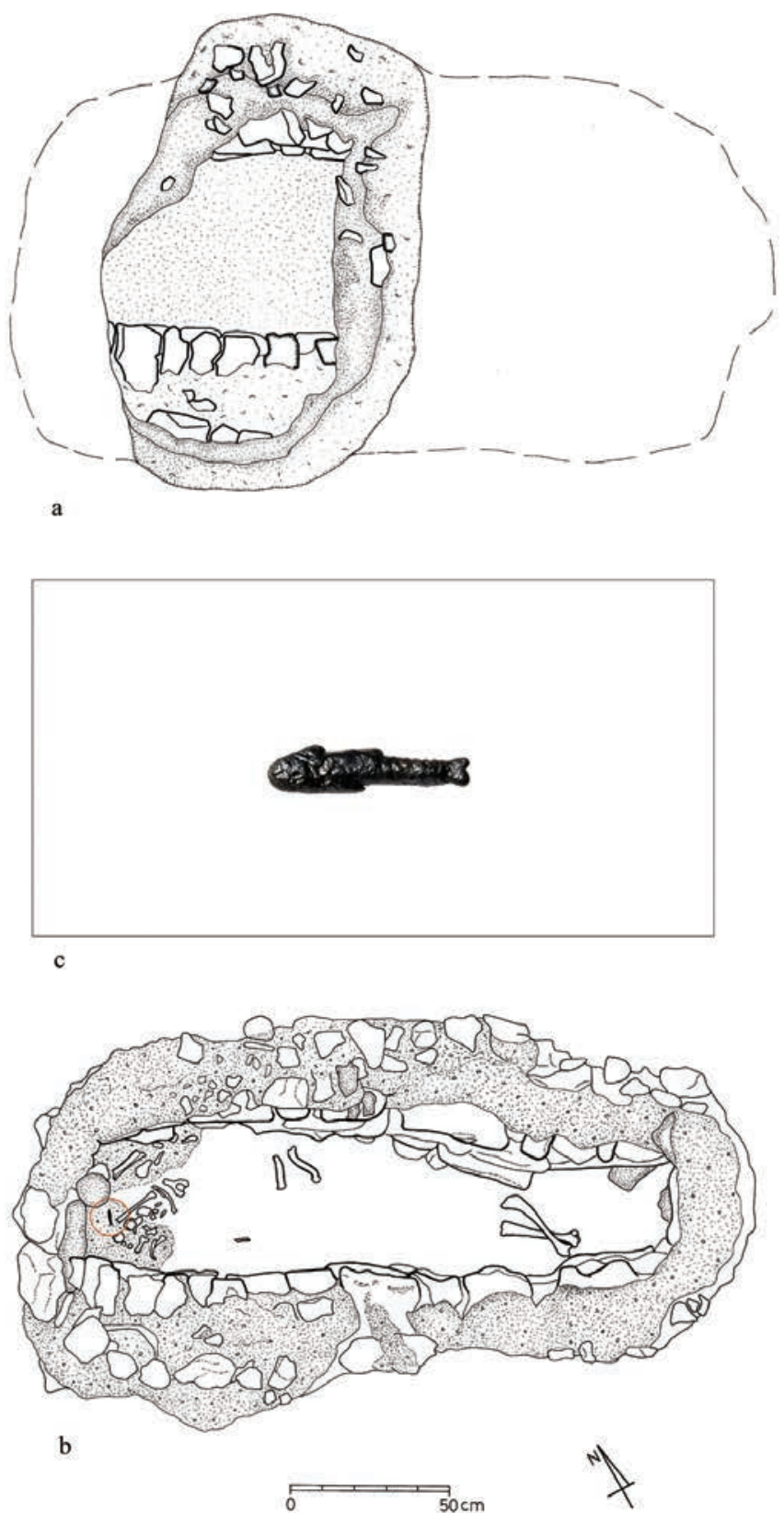

Fig. 33. Grave $22(a-b)$ with the find of fish-shaped fibula (c). Drawings: $Z$. Bakic, photo: M. Parica

site yielded the bull of the Byzantine emperor Mauritius Tiberius $(582-602)$, found as a surface find.

Prevela: Marija Kostić

\footnotetext{
${ }_{23}$ K. GUSAR, Nalazi slavenske keramike s lokaliteta Podvršje - Glavčine, Archaelogia Adriatica, 3, Zadar 2011, pp. $305-321$.

${ }^{24}$ A. UGLEŠIĆ, Podvršje - Glavčine, rezultati arheoloških istraživanja, in: Zbornik o Luji Marunu, p. 147, fig. 27-27a; A. UGLEŠIĆ, J. BARAKA, Podvršje Glavčine, un novo caso di chiese doppie in Dalmatia, p. 1215, fig. 8.
} 